\title{
The role of related strategic alliances before mergers and acquisitions
}

\section{Leonhard Brinster ${ }^{1}$ (D)}

Received: 5 July 2020 / Accepted: 23 August 2021 / Published online: 27 September 2021

(c) The Author(s) 2021

\begin{abstract}
Using mergers and acquisitions (M\&A) deals by companies from the biotechnology and pharmaceutical industry, this study analyzes the role of different types of prior ties between companies. The research distinguishes related alliances into direct and indirect alliances. Related alliances provide access to more information and can reduce transaction costs. The reduction of such costs can lead to a more successful target selection and a more efficient transaction process of the M\&A deal because the time from announcement to completion can be reduced. This effect can be explained by trust-building, better access to private information, and certification through related alliances. However, in contrast to other studies, this study does not find statistically significant evidence that supports the hypothesis that alliances increase the post-M\&A performance and that alliances are associated with higher announcement returns.
\end{abstract}

Keywords Mergers and acquisitions · Strategic alliances $\cdot$ Information costs

JEL Classifications G34 · D74 · D82

\section{Introduction}

Mergers and acquisitions (M\&As) are a channel for companies to grow, expand, enter new markets, and operate more efficiently. However, a proper target selection and post-merger integration are essential factors for a successful M\&A (Bauer and Matzler 2014). The selection process before M\&As is subject to information asymmetries and adverse selection because target companies do not always have the incentive to disclose detailed information. Besides, it is a priori not clear whether integration will lead to higher economies of scale because the success of the

Leonhard Brinster

leo.brinster@gmx.de

1 University of Hohenheim, Chair of Corporate Finance, Wollgrasweg 49, 70599 Stuttgart, Germany 
post-merger integration is uncertain. Strategic alliances can potentially reduce those risks and increase the probability of a subsequent successful M\&A.

As argued in the literature, direct and indirect (economic) ties affect corporate outcomes. Harford et al. (2019) show that economic links between firms, such as trade relationships between customers and suppliers, are important and that such links can explain the pattern and impact on merger activity. Furthermore, Gulati (1995b) argues that indirect ties end in direct ties. Gulati (1995b) analyzes prior direct and indirect alliances and their effect on future alliances. My study extends such an analysis by examining the effect of prior direct and indirect alliances on the future M\&A outcome. Moreover, this paper analyzes the role of different types of related alliances before M\&As. Furthermore, the study distinguishes between two types of prior ties (related alliances) that can be separated into direct and indirect alliances. First-degree ties are direct alliances, that is, the acquirer and the target company entered a strategic alliance before M\&A announcement. Second-degree ties are indirect alliances.

Figure 1 illustrates these relationships in a small network. On the left-hand side of the figure, in a time prior to $t_{1}$, the acquirer A entered a strategic alliance with a company $\mathrm{W}$, which is potentially a future target candidate. Later, the acquirer $\mathrm{A}$ acquires company $\mathrm{W}$ in $t_{1}$. The right-hand side of the figure depicts the situation with indirect alliances. Both companies, acquirer A and company $\mathrm{V}$, have a strategic alliance with company $\mathrm{X}$ in a time prior to $t_{1}$. Then, acquirer $\mathrm{A}$ and company $\mathrm{V}$ do not have a direct relationship. However, because they have a common partner, both companies are indirectly connected, and company $\mathrm{V}$ might be a potential target candidate. Eventually, acquirer A acquires company $\mathrm{V}$ in $t_{1}$.

The acquirer company often lacks private information about potential targets, especially about private companies. Generally, this is because the acquirer company finds it difficult to estimate the correct value of the target's assets (see, e.g., Capron and Shen 2007). Furthermore, search difficulty increases with geographical distances (Chakrabarti and Mitchell 2013). Studies show that these frictions can be

$1^{\text {st }}$ grade ties (direct alliances)

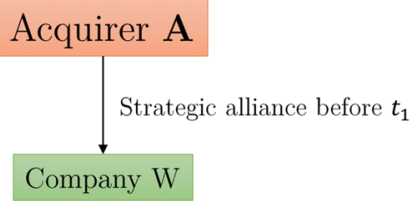

Acquirer A

M\&A-deal in $t_{1}$

Company W $2^{\text {nd }}$ grade ties (indirect alliances)
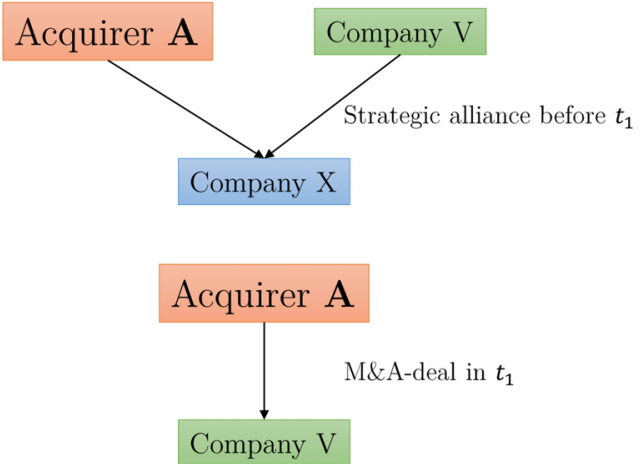

Fig. 1 Prior alliance-ties 
reduced by prior experience with M\&As (Cuypers et al. 2017), or strategic alliances (see, e.g., Chang and Tsai 2013; Fang et al. 2015), and thus lead to more successful M\&As and higher post-M\&A returns. However, in these studies, the prior experience was measured as general experience with strategic alliances. My study contributes to the literature by distinguishing between direct and indirect alliances. In such cases, strategic alliances can potentially mitigate asymmetric information if the acquirer and target companies enter a strategic partnership before the transaction. Although alliances are seemingly beneficial for both companies, in practice, cases in which a strategic partner acquires the other partner rarely happen due to several reasons. According to Hagedoorn and Sadowski (1999), the "transition from strategic technology alliances to merger and acquisition hardly ever takes place." They report that $2.6 \%$ of strategic technology alliances end in an M\&A. Further, in the study by He et al. (2018), less than $2 \%$ of M\&A deals were deals where both companies had a previous strategic alliance. The decision to enter a strategic alliance before an M\&A is a trade-off between benefits and risks. Potential reasons why companies do not enter into alliances include, for example, the fear or risk of expropriation and moral hazard (Diestre and Rajagopalan 2012; Rothaermel 2001a, b; Rothaermel and Deeds 2004; Yang et al. 2014). Besides, M\&As and strategic alliances are often considered as substitutes when it comes to the choice of governance. Gulati et al. (2009) show that prior alliances are associated more with future alliances than M\&As. Villalonga and McGahan (2005) argue that the "history of dyadic ties" predicts the future choice of the type of deal that the firms will engage. That is, companies that have a (successful) history in strategic alliances will most likely choose strategic alliances over acquisitions in the future.

Due to the aforementioned risks, acquirer and target companies often do not ally before an M\&A. However, from a theoretical perspective, strategic alliances have a positive impact on the probability that a deal occurs and on the efficiency of the transaction process. I propose that acquirers gain access to private information about a potential target directly and also indirectly through strategic alliances. Companies that entered into strategic alliances in the past share private information, which can lead to trust-building and eventually reduce transaction costs.

Other examples in the literature show that prior ties between the acquirer and target have a positive effect on the acquirer's post-M\&A returns. For example, Higgins and Rodriguez (2006) show that prior access to information about research and development activities at the target company through pre-acquisition alliances is associated with the acquirer's positive returns. Cai and Sevilir (2012) analyze the role of prior board connections and demonstrate that such ties can facilitate communication and information flow between the acquirer and the target. Eventually, this can lead to higher announcement returns in transactions with prior ties between both parties.

Regarding post-M\&A performance, there are mixed results in the literature. A recent study by $\mathrm{He}$ et al. (2018) shows a positive effect of prior direct alliances on return on assets, return on equity, and sales growth. However, a major limitation 
of the study by He et al. (2018) is that their analysis is based on a limited number of mergers with prior alliance ties and on a sample that includes different industries. Prior alliance ties between the acquirer and target company are highly prevalent in the software or information technology industry, hence resulting in sample selection issues. Zollo and Reuer (2010) show that prior alliance experience has no direct effect on acquisition performance. Furthermore, Cho and Arthurs (2018) find a negative, but not significant effect of prior alliance experience on acquisition performance.

In this study, I focus on a sample of United States (US)-based companies from the biotechnology and pharmaceutical industry, including 940 M\&A transactions from 1996 to 2014. Such sample construction has the following advantages. The acquirer companies operate in the same industry and are most likely similar in terms of development stage and operational targets. Furthermore, strategic alliances in the biotechnology and pharmaceutical industry are important because the results and output of these companies are associated with the patents and are, therefore, essential for the company's success.

In nearly $12 \%$ of the cases, where both companies had at least one strategic alliance at the time of the announcement of the deal, the acquirer and target company were (or are) direct strategic partners. In around $17 \%$ of the cases, where both companies had at least one strategic alliance, the acquirer and the target had prior alliance-ties indirectly through other companies. To estimate the probability that one company acquires another company, I build different samples of counterfactual M\&A deals, that is, deals that were possible but did not occur. I construct various samples of counterfactual deals that are based on different conditions, such as geography, or ownership of the target company. Furthermore, I am interested in the flow of information before the completion of M\&A deals. If prior-related alliances increase the information flow between the acquirer and target company, an M\&A deal should be completed faster, compared to deals that do not have such prior ties. Finally, if the target selection and the transaction process is more efficient and successful with prior ties through related alliances, it should be visible in post-M\&A performance and announcement returns.

This study contributes to the general literature on M\&As and strategic alliances. In particular, this study contributes to the literature that deals with target selection in M\&As and the role of strategic alliances on M\&A success and performance. To my knowledge, this is the first study that distinguishes between direct and indirect alliances, their relationship with each other, and their impact on M\&As, unlike other studies that focus on the role of the position of companies in a general network. This study shows that related strategic alliances can mitigate the risks of asymmetric information, adverse selection, or moral hazard before M\&As.

The remainder of the paper is structured as follows. The next section presents the theoretical background for this study and the derivation of the hypotheses. The dataset is discussed in Sect. 3, where I also provide descriptive statistics and the methodology that is used to construct the sample of counterfactual alliances. In Sect. 4, I 
present the empirical results of the estimations. The results and their limitations are discussed in Sect. 5. Section 6 concludes.

\section{Theoretical background and hypotheses}

There are different reasons for companies to participate in M\&As. For example, companies use M\&As to grow and expand their businesses to gain from economies of scale. Other reasons can be entering a new (foreign) market, increasing market share, or improving its position among competitors. However, due to a certain degree of asymmetric information in the M\&A process, especially if the acquirer is searching for a company to acquire, most of the time, the acquirer does not have full information about the target company. As an outsider, the acquirer must gain as much information as necessary (and possible) to decide whether or not to acquire a company. However, private information about a potential target is not easy to acquire. The target company may not be willing to share all their private information before an M\&A is completed due to the possibility of exploitation. Furthermore, to determine the quality of information that the target company shares, it must be verified, which involves costs. However, in some cases, such transaction costs can be reduced through different means. One such mechanism is certification by a third party (Megginson and Weiss 1991). For example, investments by prominent $\mathrm{VC}$ investors can be viewed as a certification for the good quality of the portfolio company. Furthermore, observable resources can have a signaling function (Spence 1973). Hoenig and Henkel (2015) argue that patents, team experience, and strategic alliances can be a signal for unobservable characteristics of a venture. However, the authors were unable to confirm that patents serve as signals. They rather find empirical evidence that alliances, and partly, team experience can be viewed as credible signals for unobservable company quality.

He et al. (2018) posit the hypothesis that a prior alliance relationship between the acquirer and the target company improves information sharing, builds trust, and eventually reduces information asymmetry. Repeated alliances between companies can reduce transaction costs of future alliances Gulati (1995a). Experience and repeated interaction between two companies can lead to trust-building, and hence, to a reduction in costs associated with information asymmetries or transactions. Besides, trust and familiarity between the acquirer and a potential target company can be important in a decision-making process, because public companies have shareholders that are involved in the decision of whether or not to acquire a company. Previous ties between both companies can be a positive signal to shareholders. Assuming that strategic alliances serve as signals and that alliances can potentially reduce transaction costs through access to broader information, M\&A deals should be more likely to happen between parties that have prior ties. This leads to the first hypothesis: 
Hypothesis 1a The probability of $M \& A$ increases when both parties have prior ties through direct strategic alliances.

Previous literature argues that network embeddedness plays an important role in interorganizational relationships (Gulati 1995b, 1998, 1999; Walker et al. 1997; Yang et al. 2011; Zaheer and Bell 2005). Gulati (1995b) argues that the embeddedness in a network can facilitate new alliances and new ties. Previously unconnected companies are more likely to participate in new alliances if they have common partners. According to Gulati (1995b), such ties provide valuable information to firms about the specific capabilities and reliability of potential partners.

Furthermore, Ahuja (2000) posits that direct ties can provide access to resources and that they have knowledge-spillover benefits. However, direct ties, such as direct strategic alliances, incur costs, for example, maintenance or monitoring costs. On the contrary, indirect alliances are not associated with the same costs as direct alliances. As argued by Burt (2009), companies can benefit from indirect ties similar to direct ties, but without having to bear the same costs. Finally, Ahuja (2000) argues that the benefits of indirect ties are most likely contingent on the existing number of direct ties, that is, companies benefit more from indirect ties when they do not have existing direct ties. This leads to the second hypothesis:

Hypothesis 1b An M\&A is more likely when both parties have ties through indirect alliances and no direct alliances, and vice versa.

Investment transactions, such as M\&As or VC investments, are subject to information asymmetries between buyers and sellers, and transaction costs. Geographical distance is associated with access to information (see, e.g., Chakrabarti and Mitchell 2016; Coval and Moskowitz 1999; Sorenson and Stuart 2001) and additional risks and costs (Tykvová and Schertler 2014). Hence, transaction costs are positively correlated to the geographical distance between the acquirer and the target company. The acquirer collects information during due diligence before the M\&A is completed. As a necessity, other sources of private information, such as strategic alliances, can potentially reduce the risks of adverse selection and information asymmetries (Reuer and Ragozzino 2008) that arise due to large geographical distance. Therefore, I posit that prior ties through direct or indirect alliances can reduce the difficulties arising from geographical distances. This leads to the third hypothesis:

Hypothesis 1c The probability of an M\&A increases for companies from different states when both parties have ties through related alliances, compared to deals without such ties.

The embeddedness in a well-connected network might induce trust among connected companies and have reputation effects (see, e.g., Raub and Weesie 1990; Uzzi 1996; Villalonga and McGahan 2005). Such connectedness can reduce costs, such as target selection and other related costs that are associated with the transaction process (Gulati 1995a). Therefore, because the M\&A deal is subject to information 
asymmetries, trusting relationships can help complete a transaction faster due to better, broader, and faster access to private information through prior ties. This leads to the fourth hypothesis:

Hypothesis 2a The transaction process of an M\&A deal is completed faster, that is, the time from the announcement of the deal to its completion is shorter, when the acquirer and the target company have prior ties through related alliances, compared to deals with no related prior ties between the acquirer and the target company.

Sales of listed companies require the board of directors' approval, and shareholders need to ratify the transaction. Hence, the transaction process of an acquisition of a listed target might take a longer time than the acquisition of a private target. Building again on the theory of network embeddedness and creation of trust in repeated interactions between companies, I posit the fifth hypothesis that the time for the transaction of a listed target should be shorter for deals with prior ties through related strategic alliances.

Hypothesis 2b The transaction process of an M\&A deal is completed faster, that is, the time from the announcement of the deal to its completion is shorter, if the target company is a public company, and the acquirer, as well as the target company, have prior ties through related alliances, compared to deals with no related prior ties and where the target company is private.

Furthermore, according to Thomson SDC, cash payments were particularly more common in M\&A deals than stock payments. One of the reasons is that stock payments are a more complicated way of paying for an acquisition than cash payments because the ownership status is not demarcated after the transaction. In addition, acquirer companies that pay with stocks also share the risks of the transaction of the company they acquire, and such transactions can affect shareholder returns. One can assume that the transaction process becomes more complicated with stock payments because more subjects are involved in the decision process. However, if companies share prior ties through related alliances, the trust and certification by prior ties can encourage a faster approval time, and thus, a faster transaction process. This leads to the sixth hypothesis:

Hypothesis 2c The transaction process of an $M \& A$ deal is completed faster, that is, the time from the announcement of the deal to its completion is shorter if the payment type is stock and both parties have prior ties through related alliances, compared to deals with no related prior ties and cash payment.

If prior ties through related alliances allow companies to access additional private information about potential targets, this should reduce adverse selection problems, and thus, lead to a more efficient post-M\&A integration. Familiarity in the operations of both companies and mutual trust can increase the success of the post-merger integration process. Furthermore, general alliance experience might be supportive 
for acquisitions, for example, due to experience spillovers and absorptive capacity (see, e.g., Cohen and Levinthal 1990; Zaheer et al. 2010; Zollo and Reuer 2010). Porrini (2004) argues that the experience with previous alliances may foster a more effective and efficient post-acquisition integration process, thus leading to better acquisition performance. Therefore, acquisition performance, such as return on assets or announcement returns, should be higher for deals where both parties shared prior ties through related alliances. This leads to the seventh and eighth hypotheses:

Hypothesis 3a $M \& A$ deals with prior ties through related strategic alliances are associated with higher post-M\&A return on assets, compared to deals without related ties.

Hypothesis 3b M\&A deals with prior ties through related strategic alliance are associated with higher announcement returns, compared to deals without related ties.

\section{Data}

\section{Sample selection}

The sample contains all M\&A deals between 1990 and 2014 of US-based acquirers. Further selection criteria are: (i) announcement date between January 1, 1996, and December 31, 2014; (ii) the acquirer is a publicly-traded US company; (iii) the percentage of shares sought in the deal is at least 50\%; (iv) the deal is not a joint venture, spin-off, recapitalization, self-tender, exchange offer, repurchase, or privatization; (v) the acquirer company operates in either the biotechnology or pharmaceutical industry; and (vi) the data can be matched to CRSP stock information at the time of the announcement and Compustat financial data.

I collected the data on strategic alliances from Thomson SDC for each acquirer and target company. In the overall dataset, $71 \%$ of the acquirer companies and $27 \%$ of the target companies have at least one (related or unrelated) strategic alliance at the time of the announcement of the M\&A. The acquirer companies with at least one strategic alliance have, on average, 21 strategic alliances, and the target companies have, on average, 4.7 strategic alliances.

Table 1 shows summary statistics for realized deals in the overall sample of 940 deals. The average number of days from the announcement to the completion of the deal is around 54. The difference between the return on assets three years after and one year before the focal acquisition is, on average, -0.3546. Cumulative abnormal returns (CARs) of the acquirer in the event window $(-2,+2)$ and $(-5,+5)$ around the deal announcement date are, on average, around 0.009 and 0.007 , respectively. On average, in $23 \%$ of the deals, both companies had at least one strategic alliance (related or unrelated). In around 3\% of the deals, both companies had a prior direct alliance with each other. In around $4 \%$ of the deals, the companies were connected through indirect alliances. For all deals, there were, on average, 0.1 indirect alliances, whereby the maximum number of indirect alliances is 13 . In $77 \%$ of the 
Table 1 Summary statistics: realized deals

\begin{tabular}{llllll}
\hline & \#obs. & mean & s.d. & min & max \\
\hline Time to completion & 940 & 53.6532 & 80.6294 & 0 & 862 \\
$\Delta R O A_{(t+3) /(t-1)}$ & 560 & -0.3546 & 23.4345 & -445.8625 & 294.3645 \\
CAR[-2,+2] & 608 & 0.0086 & 0.1262 & -0.4054 & 1.4344 \\
CAR[-5, +5] & 608 & 0.0074 & 0.1600 & -0.5676 & 1.7071 \\
Dummy both alliance & 940 & 0.2255 & 0.4182 & 0 & 1 \\
Dummy direct alliance & 940 & 0.0277 & 0.1641 & 0 & 1 \\
Dummy indirect alliance & 940 & 0.0372 & 0.1894 & 0 & 1 \\
Number indirect alliances & 940 & 0.0777 & 0.5721 & 0 & 13 \\
Private target & 940 & 0.7660 & 0.4236 & 0 & 1 \\
Cross-border deal & 940 & 0.2138 & 0.4102 & 0 & 1 \\
Same state & 940 & 0.2117 & 0.4087 & 0 & 1 \\
Payment & 830 & 2.5687 & 1.2169 & 1 & 4 \\
Hostile takeover & 924 & 0.0022 & 0.0465 & 0 & 1 \\
Divestiture & 924 & 0.0152 & 0.1222 & 0 & 1 \\
Tender offer & 924 & 0.0617 & 0.2407 & 0 & 1 \\
Unsolicited & 924 & 0.0076 & 0.0868 & 0 & 1 \\
Rumor & 940 & 0.0223 & 0.1479 & 0 & 1 \\
\hline
\end{tabular}

This table shows descriptive statistics for different variables that are calculated by the time of the announcement of the M\&A deal. Time to completion is non-negative and counts the days between the announcement and completion date of an M\&A deal. $\triangle R O A_{(t+3) /(t-1)}$ is the difference between the return on assets three years after and one year before the focal acquisition. $C A R[-2,+2]$ and $C A R[-5,+5]$ are cumulative abnormal return of the acquirer in the event window $(-2,+2)$, respectively $(-5,+5)$, around the deal announcement date. Dummy both alliance is a dummy variable that equals one if the acquirer and the target company had at least one strategic alliance (unrelated or related) prior to the M\&A deal, and zero otherwise. Dummy direct alliance is a dummy variable that equals one if the acquirer and the target company had a direct strategic alliance prior to the M\&A deal, and zero otherwise. Dummy indirect alliance is a dummy variable that equals one if the acquirer and the target company had an indirect strategic alliance prior to the M\&A deal, and zero otherwise. Number indirect alliances counts the number of indirect alliances between the acquirer and the target company. Private target is a dummy variable that equals one if the target was a private company prior to the M\&A deal, and zero otherwise. Crossborder deal is a dummy variable that equals one if the target was a non-US company, and zero otherwise. Same state is a dummy variable that equals one if the acquirer and the target company were in the same US-state, and zero otherwise. Payment is a factor variable and takes on the values 1 for cash payment, 2 for mixed payment, 3 for stock payment, and 4 for other payment. Hostile takeover is a dummy variable that equals one if the deal is characterized as a hostile takeover, and zero otherwise. Divestiture is a dummy variable that equals one if the M\&A deal was a divestiture sale, and zero otherwise. Tender offer is a dummy variable that equals one if the acquirer offers its stock in the M\&A deal, and zero otherwise. Unsolicited is a dummy variable that equals one if the offer was unsolicited, and zero otherwise. Rumor is a dummy variable that equals one if the $\mathrm{M} \& \mathrm{~A}$ deal started as a rumor, and zero otherwise

cases, a private company was acquired and in $22 \%$ of the cases, a non-US target was acquired. In $21 \%$ of the deals, both companies were located in the same US-state. The variable Payment is a factor variable and takes on the values 1 for cash payment, 2 for mixed payment, 3 for stock payment, and 4 for other payment. A total of 250 deals were paid with cash (26.60\%). In 120 deals, the payment type was mixed $(12.77 \%)$, and in 198 deals, the payment type was stock $(21.06 \%)$. The remaining 
262 deals were paid by another payment type (27.87\%). For 110 deals, the payment type was undisclosed $(11.70 \%)$. The sample contains control variables for deal characteristics. Five different variables indicate whether the deal was a hostile takeover, a divestiture, a tender offer, an unsolicited deal, or started as a rumor.

\section{Creation of counterfactuals and descriptive statistics}

It is necessary to have variation in the dependent variable to estimate the relationship between two variables, or the effect of one variable on another. This study analyzes whether prior ties through strategic alliances are related to the probability of an M\&A. However, one can only observe deals that were realized in the past. Therefore, this study needs data in the sample that depicts counterfactual deals, that is, deals that were possible but did not happen, and hence, create variation in the dependent variable. The challenge is to construct counterfactual deals where only one factor-the fact that one deal was realized and the other was not-differs, and other characteristics remain the same or very similar. In practice, most of the time this is difficult to construct, because one can only include variables that are observable. For that reason, I construct different counterfactual samples that vary in terms of restrictions to the main sample. With such restrictions, one can eliminate, or at least, mitigate potential biases from unobservable characteristics, and hence, confirm the robustness of the estimation results.

Counterfactual deals are based on a function that maps the elements of $\boldsymbol{Y}$ to $\boldsymbol{X}$. The codomain $\boldsymbol{Y}$ is the set of all target companies, and the domain $\boldsymbol{X}$ contains all acquirer companies from M\&A deals between 1996 and 2014 in the biotechnology or pharmaceutical industry. Furthermore, the function maps six elements of $\boldsymbol{Y}$ for each element in $\boldsymbol{X}$, under the condition that the announcement dates of those deals in $\boldsymbol{Y}$ are the closest in time to the actual announcement date of elements in $\boldsymbol{X}$.

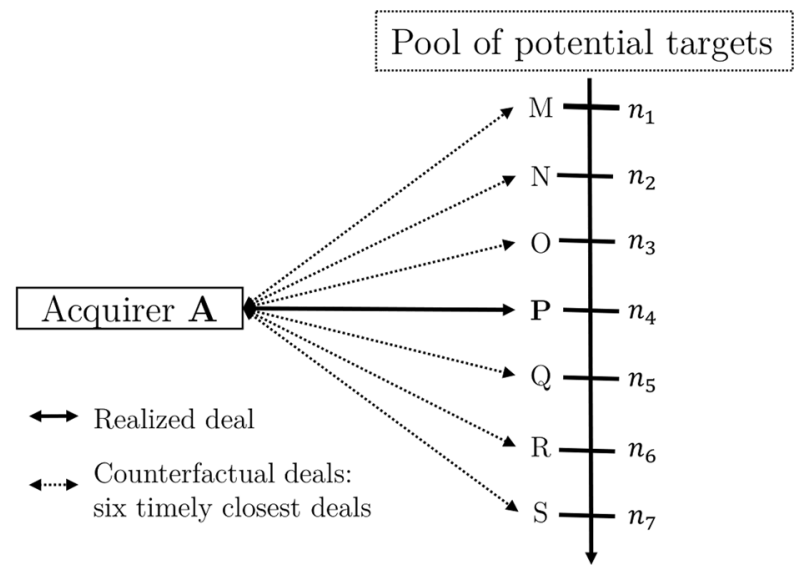

Fig. 2 Counterfactual deals built by mapping potential targets to acquirers 


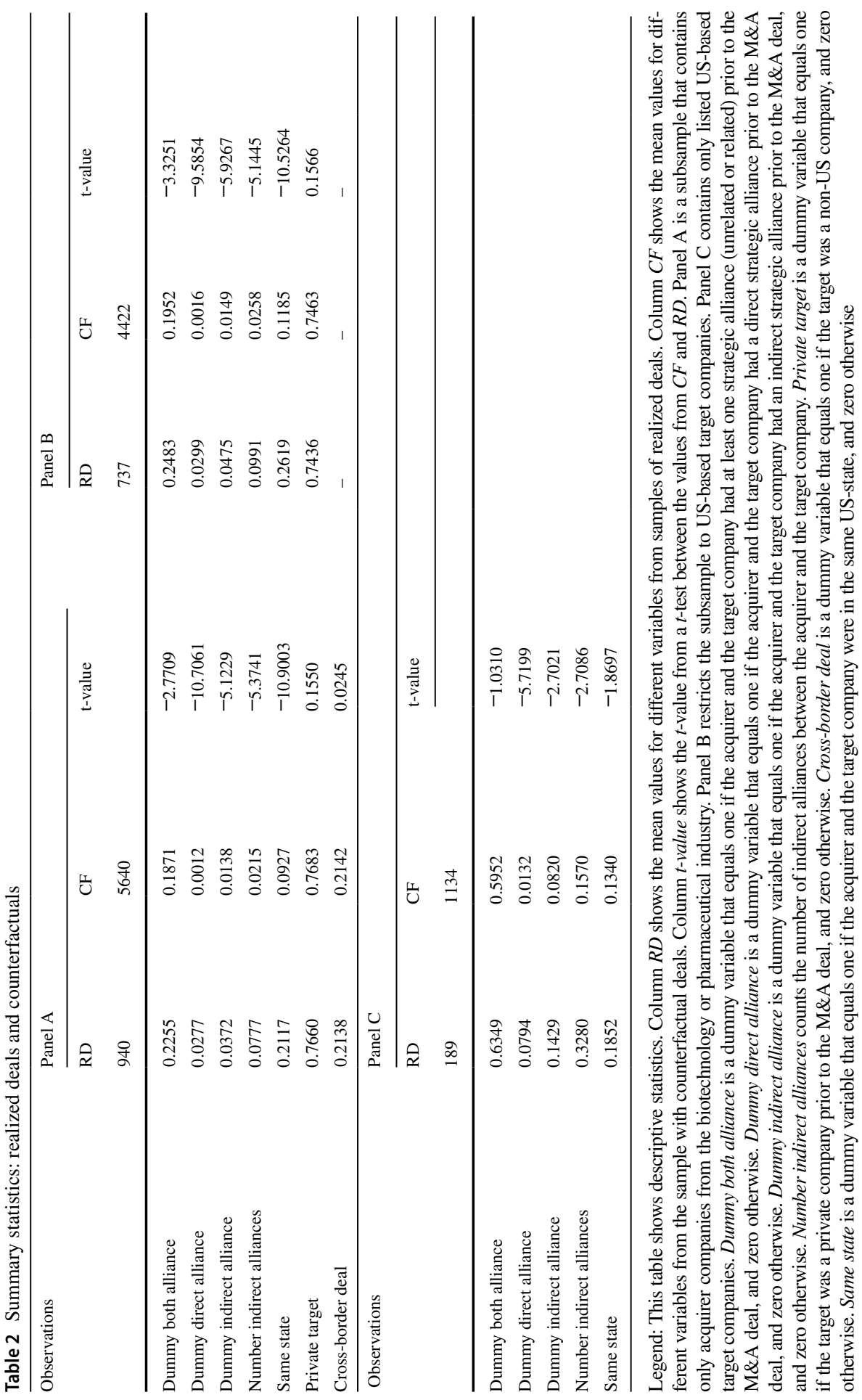


Table 3 Probability of an M\&A deal: estimations with counterfactuals

\begin{tabular}{|c|c|c|c|c|c|c|}
\hline DV: Realized deal & (1) & $(2)$ & (3) & (4) & $(5)$ & (6) \\
\hline \multicolumn{7}{|c|}{ Panel A: acquirer is from the biotechnology or pharmaceutical industry } \\
\hline Dummy both alliance & $\begin{array}{l}0.0352 * * * \\
(0.0113)\end{array}$ & $\begin{array}{l}0.0205^{*} \\
(0.0117)\end{array}$ & $\begin{array}{l}0.0240 * * \\
(0.0119)\end{array}$ & $\begin{array}{l}0.0113 \\
(0.0122)\end{array}$ & $\begin{array}{l}0.0270 * * \\
(0.0117)\end{array}$ & $\begin{array}{l}0.0136 \\
(0.0121)\end{array}$ \\
\hline Dummy direct alliance & & $\begin{array}{l}0.3905 * * * \\
(0.0566)\end{array}$ & & $\begin{array}{l}0.3796 * * * \\
(0.0582)\end{array}$ & & $\begin{array}{l}0.3801 * * * \\
(0.0580)\end{array}$ \\
\hline Dummy indirect alliance & & & $\begin{array}{l}0.1154 * * * \\
(0.0270)\end{array}$ & $\begin{array}{l}0.1015 * * * \\
(0.0292)\end{array}$ & & \\
\hline Number indirect alliances & & & & & $\begin{array}{l}0.0523 * * * \\
(0.0154)\end{array}$ & $\begin{array}{l}0.0484 * * * \\
(0.0159)\end{array}$ \\
\hline Private target & $\begin{array}{l}0.0121 \\
(0.0111)\end{array}$ & $\begin{array}{l}0.0142 \\
(0.0113)\end{array}$ & $\begin{array}{l}0.0160 \\
(0.0113)\end{array}$ & $\begin{array}{l}0.0174 \\
(0.0114)\end{array}$ & $\begin{array}{l}0.0158 \\
(0.0113)\end{array}$ & $\begin{array}{l}0.0173 \\
(0.0114)\end{array}$ \\
\hline Cross-border deal & $\begin{array}{l}0.0019 \\
(0.0108)\end{array}$ & $\begin{array}{l}0.0019 \\
(0.0107)\end{array}$ & $\begin{array}{l}0.0027 \\
(0.0108)\end{array}$ & $\begin{array}{l}0.0026 \\
(0.0107)\end{array}$ & $\begin{array}{l}0.0023 \\
(0.0108)\end{array}$ & $\begin{array}{l}0.0022 \\
(0.0108)\end{array}$ \\
\hline Year FE & Yes & Yes & Yes & Yes & Yes & Yes \\
\hline$N$ & 6,580 & 6,580 & 6,580 & 6,580 & 6,580 & 6,580 \\
\hline \multicolumn{7}{|c|}{ Panel B: US-based target companies } \\
\hline Dummy both alliance & $\begin{array}{l}0.0446 * * * \\
(0.0121)\end{array}$ & $\begin{array}{l}0.0310 * * \\
(0.0124)\end{array}$ & $\begin{array}{l}0.0303 * * \\
(0.0128)\end{array}$ & $\begin{array}{l}0.0196 \\
(0.0130)\end{array}$ & $\begin{array}{l}0.0370 * * * \\
(0.0125)\end{array}$ & $\begin{array}{l}0.0257 * * \\
(0.0131)\end{array}$ \\
\hline Dummy direct alliance & & $\begin{array}{l}0.3615 * * * \\
(0.0552)\end{array}$ & & $\begin{array}{l}0.3420 * * * \\
(0.0584)\end{array}$ & & $\begin{array}{l}0.3450 * * * \\
(0.0582)\end{array}$ \\
\hline Dummy indirect alliance & & & $\begin{array}{l}0.1317 * * * \\
(0.0280)\end{array}$ & $\begin{array}{l}0.1126 * * * \\
(0.0305)\end{array}$ & & \\
\hline Number indirect alliances & & & & & $\begin{array}{l}0.0435 * * \\
(0.0197)\end{array}$ & $\begin{array}{l}0.0360 \\
(0.0254)\end{array}$ \\
\hline Private target & $\begin{array}{l}0.0167 \\
(0.0119)\end{array}$ & $\begin{array}{l}0.0198 \\
(0.0120)\end{array}$ & $\begin{array}{l}0.0211^{*} \\
(0.0121)\end{array}$ & $\begin{array}{l}0.0231 * \\
(0.0122)\end{array}$ & $\begin{array}{l}0.0201 * \\
(0.0121)\end{array}$ & $\begin{array}{l}0.0220 * \\
(0.0122)\end{array}$ \\
\hline Same state & $\begin{array}{l}0.1174 * * * \\
(0.0113)\end{array}$ & $\begin{array}{l}0.1182 * * * \\
(0.0113)\end{array}$ & $\begin{array}{l}0.1173^{* * * *} \\
(0.0113)\end{array}$ & $\begin{array}{l}0.1180 * * * \\
(0.0113)\end{array}$ & $\begin{array}{l}0.1170 * * * \\
(0.0114)\end{array}$ & $\begin{array}{l}0.1180 * * * \\
(0.0113)\end{array}$ \\
\hline Year FE & Yes & Yes & Yes & Yes & Yes & Yes \\
\hline$N$ & 5,159 & 5,159 & 5,159 & 5,159 & 5,159 & 5,159 \\
\hline \multicolumn{7}{|c|}{ Panel C: listed US-based target companies } \\
\hline Dummy both alliance & $\begin{array}{l}0.0245 \\
(0.0216)\end{array}$ & $\begin{array}{l}0.0089 \\
(0.0216)\end{array}$ & $\begin{array}{l}0.0118 \\
(0.0221)\end{array}$ & $\begin{array}{l}0.0018 \\
(0.0219)\end{array}$ & $\begin{array}{l}0.0169 \\
(0.0218)\end{array}$ & $\begin{array}{l}0.0065 \\
(0.0216)\end{array}$ \\
\hline Dummy direct alliance & & $\begin{array}{l}0.2327 * * * \\
(0.0463)\end{array}$ & & $\begin{array}{l}0.2159 * * * \\
(0.0490)\end{array}$ & & $\begin{array}{l}0.2180 * * * \\
(0.0499)\end{array}$ \\
\hline Dummy indirect alliance & & & $\begin{array}{l}0.0768 * * \\
(0.0301)\end{array}$ & $\begin{array}{l}0.0502 \\
(0.0330)\end{array}$ & & \\
\hline Number indirect alliances & & & & & $\begin{array}{l}0.0236 * * \\
(0.0095)\end{array}$ & $\begin{array}{l}0.0111 \\
(0.0119)\end{array}$ \\
\hline Same state & $\begin{array}{l}0.0519 * * \\
(0.0262)\end{array}$ & $\begin{array}{l}0.0532 * * \\
(0.0255)\end{array}$ & $\begin{array}{l}0.0540 * * \\
(0.0262)\end{array}$ & $\begin{array}{l}0.0545^{* *} \\
(0.0254)\end{array}$ & $\begin{array}{l}0.0522 * * \\
(0.0262)\end{array}$ & $\begin{array}{l}0.0533 * * \\
(0.0255)\end{array}$ \\
\hline Year FE & Yes & Yes & Yes & Yes & Yes & Yes \\
\hline
\end{tabular}


Table 3 (continued)

\begin{tabular}{lllllll}
\hline DV: Realized deal & $(1)$ & $(2)$ & $(3)$ & $(4)$ & $(5)$ & $(6)$ \\
\hline$N$ & 1,323 & 1,323 & 1,323 & 1,323 & 1,323 & 1,323 \\
\hline
\end{tabular}

This table shows partial effects at the averages (PEA) of logistic regressions. The dependent variable is a dummy variable that equals one if a deal was realized, and zero otherwise. Panel A is a subsample that contains only acquirer companies from the biotechnology or pharmaceutical industry. Panel B restricts the subsample to US-based target companies. Panel C contains only listed US-based target companies. Dummy both alliance is a dummy variable that equals one if the acquirer and the target company had at least one strategic alliance (unrelated or related) prior to the M\&A deal, and zero otherwise. Dummy direct alliance is a dummy variable that equals one if the acquirer and the target company had a direct strategic alliance prior to the M\&A deal, and zero otherwise. Dummy indirect alliance is a dummy variable that equals one if the acquirer and the target company had an indirect strategic alliance prior to the M\&A deal, and zero otherwise. Number indirect alliances counts the number of indirect alliances between the acquirer and the target company. Private target is a dummy variable that equals one if the target was a private company prior to the M\&A deal, and zero otherwise. Cross-border deal is a dummy variable that equals one if the target was a non-US company, and zero otherwise. Same state is a dummy variable that equals one if the acquirer and the target company were in the same US-state, and zero otherwise. A constant is included in all regressions. Robust standard errors are displayed in parentheses. *, **, and $* * *$ indicate statistical significance at the $10 \%, 5 \%$, and $1 \%$ levels, respectively

Figure 2 illustrates the mapping. As an example, consider acquirer company A, which closed an M\&A deal with target company $\mathbf{P}$. There were also other M\&A deals in the biotechnology and pharmaceutical industry around that time. The sequence $n$ is sorted by the announcement time of the deals. The target companies $\mathrm{M}, \mathrm{N}, \mathrm{O}, \mathrm{Q}, \mathrm{R}$, and $\mathrm{S}$, are considered to be potential target companies for the acquirer company $\mathbf{A}$.

To estimate the relationship between strategic alliances and the probability of an M\&A, I create three different samples of counterfactual deals. In the first sample, I only include biotechnology and pharmaceutical companies. For each pair of acquirer and target, that is, an actual M\&A deal, I create counterfactual deals that were potentially possible at that time but did not happen. Given that I only consider biotechnology or pharmaceutical companies, it is reasonable to assume that target companies in timely close deals were also possible targets for the acquirer companies in actual deals. The second sample is restricted to US-based targets, that is, domestic deals. With such a restriction, it is possible to mitigate cultural distances and account for geographical distance precisely. Finally, the third sample contains only listed target companies.

Table 2 shows summary statistics for different counterfactual samples. Panel A contains the most deals (940). Panel B, which restricts the sample to US-based target companies, contains 737 realized deals. The smallest sample is Panel C, which contains 189 realized deals and further restricts the sample to only public US-based target companies. The mean value of the dependent variable Realized deal is equal to 0.1429 , because, in all the three panels, the number of counterfactual deals that are matched to each realized deal is the same. 


\section{Results}

\section{The probability of a successful M\&A}

Table 3 shows partial effects at the averages of logistic regressions for different panels. The first panel of the counterfactual sample contains 940 realized and 5640 counterfactual deals. As a reference category, I include a dummy variable that equals one if both companies entered at least one related or unrelated strategic alliance, and zero otherwise. With such a setting, it is possible to estimate the additional effects of related alliances. In columns 1, 2, 3, and 4, the coefficient of Dummy both alliance is statistically significant and positive. Hence, when both companies engage in previous unrelated or related strategic alliances, those company pairs are, on average, associated with a 2-3.5 percentage points higher probability of a completed M\&A deal.

Furthermore, I include measures for related strategic alliances in the next estimations. The variable Dummy direct alliance equals one if both companies participated in a strategic alliance with each other before the M\&A, and zero otherwise. The next two variables capture prior ties through indirect strategic alliances. Dummy indirect alliance equals one if there was at least one indirect strategic alliance between both companies, and zero otherwise. The variable Number indirect alliances counts the number of indirect strategic alliances before the M\&A. In all the estimations, the coefficients of the measures for related strategic alliances are statistically significant and positive, thus indicating a positive relationship between the completed M\&A and related strategic alliances. Dummy direct alliance is associated with a 39 percentage points higher likelihood that an M\&A will be completed (column 2) and Dummy indirect alliance is associated with around 12 percentage points higher likelihood that an M\&A will be completed (column 3), compared to the reference category. When both measures are included in one estimation (column 4), the coefficients remain statistically significant and positive, meaning that both types of related alliances are associated with a higher probability of completed M\&As. In the last two estimations (columns 4 and 5), I replace the dummy variable that measures indirect strategic alliances with a count variable for indirect strategic alliances. The coefficient of the variable Number indirect alliances is statistically significant and positive thus indicating that a higher number of prior ties through indirect strategic alliances is associated with a higher probability of a completed M\&A. In all the estimations, I control for private targets, cross-border deals, and year fixed effects. However, the coefficients of the variables of Private target and Cross-border deal are statistically not significant.

Panel B shows the results for a subsample that contains only US-based target companies. This sample includes 737 realized and 4422 counterfactual deals. I use this sample to control whether related alliances are associated with a higher likelihood of completed M\&As when controlling for distance. It is possible to include a distance variable in the previous sample; however, this would be somewhat problematic because, for example, the distance between the US and Europe is significant, 
Table 4 Probability of an M\&A deal: estimations with interaction terms

\begin{tabular}{|c|c|c|c|c|c|c|}
\hline \multirow[b]{2}{*}{ DV: Realized deal } & \multicolumn{2}{|l|}{ Panel A } & \multicolumn{2}{|l|}{ Panel B } & \multicolumn{2}{|l|}{ Panel C } \\
\hline & (1) & (2) & (3) & (4) & (5) & (6) \\
\hline Dummy both alliance & $\begin{array}{l}0.0101 \\
(0.0122)\end{array}$ & $\begin{array}{l}0.0120 \\
(0.0122)\end{array}$ & $\begin{array}{l}0.0180 \\
(0.0134)\end{array}$ & $\begin{array}{l}0.0211 \\
(0.0135)\end{array}$ & $\begin{array}{l}-0.0021 \\
(0.0212)\end{array}$ & $\begin{array}{l}-0.0001 \\
(0.0212)\end{array}$ \\
\hline Dummy direct alliance & $\begin{array}{l}0.6962 * * * \\
(0.0772)\end{array}$ & $\begin{array}{l}0.6685 * * * \\
(0.0726)\end{array}$ & $\begin{array}{l}0.6978 * * * \\
(0.0832)\end{array}$ & $\begin{array}{l}0.6786 * * * \\
(0.0782)\end{array}$ & $\begin{array}{l}0.5446 * * * \\
(0.1223)\end{array}$ & $\begin{array}{l}0.4398 * * * \\
(0.1051)\end{array}$ \\
\hline Dummy indirect alliance & $\begin{array}{l}0.1421 * * * \\
(0.0451)\end{array}$ & & $\begin{array}{l}0.1762 * * * \\
(0.0499)\end{array}$ & & $\begin{array}{l}0.0867 * * \\
(0.0424)\end{array}$ & \\
\hline Number indirect alliances & & $\begin{array}{l}0.0742 * * * \\
(0.0262)\end{array}$ & & $\begin{array}{l}0.0857 * * * \\
(0.0298)\end{array}$ & & $\begin{array}{l}0.0389 * \\
(0.0205)\end{array}$ \\
\hline $\begin{array}{l}\text { Dummy direct alliance } \\
\mathrm{x} \text { Dummy indirect alliance }\end{array}$ & $\begin{array}{l}-0.2218 \\
(0.1768)\end{array}$ & & $\begin{array}{l}-0.3345^{*} \\
(0.1814)\end{array}$ & & $\begin{array}{l}-0.3942 * * \\
(0.1822)\end{array}$ & \\
\hline $\begin{array}{l}\text { Dummy direct alliance } \\
\text { x Number indirect alliances }\end{array}$ & & $\begin{array}{l}-0.0658 * * \\
(0.0289)\end{array}$ & & $\begin{array}{l}-0.1141 * * * \\
(0.0404)\end{array}$ & & $\begin{array}{l}-0.0656 \\
(0.0400)\end{array}$ \\
\hline Private target & $\begin{array}{l}0.0168 \\
(0.0107)\end{array}$ & $\begin{array}{l}0.0170 \\
(0.0107)\end{array}$ & $\begin{array}{l}0.0229 * \\
(0.0117)\end{array}$ & $\begin{array}{l}0.0230 * * \\
(0.0117)\end{array}$ & & \\
\hline Cross-border deal & $\begin{array}{l}0.0024 \\
(0.0107)\end{array}$ & $\begin{array}{l}0.0022 \\
(0.0107)\end{array}$ & & & & \\
\hline Same state & & & $\begin{array}{l}0.1488 * * * \\
(0.0173)\end{array}$ & $\begin{array}{l}0.1491 * * * \\
(0.0173)\end{array}$ & $\begin{array}{l}0.0582 * \\
(0.0309)\end{array}$ & $\begin{array}{l}0.0609 * * \\
(0.0310)\end{array}$ \\
\hline Year FE & Yes & Yes & Yes & Yes & Yes & Yes \\
\hline$N$ & 6,580 & 6,580 & 5,159 & 5,159 & 1,323 & 1,323 \\
\hline
\end{tabular}

This table shows results of OLS estimations. The dependent variable is a dummy variable that equals one if a deal was realized, and zero otherwise. Panel A is a subsample that contains only acquirer companies from the biotechnology or pharmaceutical industry. Panel B restricts the subsample to US-based target companies. Panel C contains only listed US-based target companies. Dummy both alliance is a dummy variable that equals one if the acquirer and the target company had at least one strategic alliance (unrelated or related) prior to the M\&A deal, and zero otherwise. Dummy direct alliance is a dummy variable that equals one if the acquirer and the target company had a direct strategic alliance prior to the M\&A deal, and zero otherwise. Dummy indirect alliance is a dummy variable that equals one if the acquirer and the target company had an indirect strategic alliance prior to the M\&A deal, and zero otherwise. Number indirect alliances counts the number of indirect alliances between the acquirer and the target company. Private target is a dummy variable that equals one if the target was a private company prior to the M\&A deal, and zero otherwise. Cross-border deal is a dummy variable that equals one if the target was a non-US company, and zero otherwise. Same state is a dummy variable that equals one if the acquirer and the target company were in the same US-state, and zero otherwise. A constant is included in all regressions. Robust standard errors are displayed in parentheses. *, **, and *** indicate statistical significance at the $10 \%, 5 \%$, and $1 \%$ levels, respectively

compared to the distances within the US. This would lead to biased results because of the distribution of the distance variable.

Similar to the previous estimations with Panel A, I include a dummy variable that equals one if both companies entered into at least one related or unrelated strategic alliance, and zero otherwise. The coefficient of the variable Dummy both alliance is statistically significant and positive in all columns except for column 4 . 
The measures for related strategic alliances are statistically significant and positive in all regressions, except for column 6 , where the coefficient of the variable Number indirect alliances is statistically not significant. Further, the magnitudes of the coefficients are similar to the results in the previous estimations with Panel A, thus indicating robust results. This illustrates an important association between related alliances and the probability of a successful M\&A deal. Another result is that when both companies are located in the same US-state, the probability of a completed

Table 5 Probability of an M\&A deal: analysis with counterfactuals, distance

Subsample: US-based target companies (Panel B)

\begin{tabular}{|c|c|c|c|c|}
\hline DV: Realized deal & (1) & (2) & (3) & (4) \\
\hline Not same state & $\begin{array}{l}-0.1525^{* * * *} \\
(0.0194)\end{array}$ & $\begin{array}{l}-0.1487 * * * \\
(0.0174)\end{array}$ & $\begin{array}{l}-0.1494 * * * \\
(0.0175)\end{array}$ & $\begin{array}{l}-0.1496^{* * *} \\
(0.0175)\end{array}$ \\
\hline Dummy both alliance & $\begin{array}{l}0.0352 \\
(0.0422)\end{array}$ & $\begin{array}{l}0.0322 * * \\
(0.0134)\end{array}$ & $\begin{array}{l}0.0316 * * \\
(0.0137)\end{array}$ & $\begin{array}{l}0.0379 * * * \\
(0.0138)\end{array}$ \\
\hline Dummy direct alliance & & $\begin{array}{l}0.7204 * * * \\
(0.0234)\end{array}$ & & \\
\hline Dummy indirect alliance & & & $\begin{array}{l}0.1844 \\
(0.1302)\end{array}$ & \\
\hline Number indirect alliances & & & & $\begin{array}{l}0.0461 * * \\
(0.0217)\end{array}$ \\
\hline Dummy both alliance & 0.0149 & & & \\
\hline x Not same state & $(0.0440)$ & & & \\
\hline Dummy direct alliance & & -0.1042 & & \\
\hline x Not same state & & $(0.0907)$ & & \\
\hline Dummy indirect alliance & & & 0.0121 & \\
\hline x Not same state & & & $(0.1396)$ & \\
\hline Number indirect alliances & & & & 0.0271 \\
\hline x Not same state & & & & $(0.0388)$ \\
\hline Controls & Yes & Yes & Yes & Yes \\
\hline Year FE & Yes & Yes & Yes & Yes \\
\hline$N$ & 5159 & 5159 & 5159 & 5159 \\
\hline
\end{tabular}

This table shows results of OLS estimations. The dependent variable is a dummy variable that equals one if a deal was realized, and zero otherwise. This sample contains only deals where the target company is US-based. Not same state is a dummy variable that equals one if the acquirer and target company were not in the same US-state. Dummy both alliance is a dummy variable that equals one if the acquirer and the target company had at least one strategic alliance (unrelated or related) prior to the M\&A deal, and zero otherwise. Dummy direct alliance is a dummy variable that equals one if the acquirer and the target company had a direct strategic alliance prior to the M\&A deal, and zero otherwise. Dummy indirect alliance is a dummy variable that equals one if the acquirer and the target company had an indirect strategic alliance prior to the M\&A deal, and zero otherwise. Number indirect alliances counts the number of indirect alliances between the acquirer and the target company. Other control variables as well as a constant are included in all regressions. Robust standard errors are displayed in parentheses. *, **, and *** indicate statistical significance at the $10 \%, 5 \%$, and $1 \%$ levels, respectively 
M\&A deal increases by around 12 percentage points. The coefficients of the variable Same state stay similar in statistical significance and magnitude in all regressions.

Panel $\mathrm{C}$ of Table 3 shows the results for the subsample with M\&A deals where the target companies were listed on the stock exchange and their headquarters located in the US. The sample contains 189 realized and 1134 counterfactual deals. This setting excludes the effects of cross-border and private target deals. Contrary to the estimations in Panel A and Panel B, the coefficient of the variable Dummy both alliance is not statistically significant in any of the regression models. However, the coefficients of the dummy variables that measure the involvement of either direct or indirect strategic alliances are statistically significant. In this scenario, the coefficients are somewhat smaller in magnitude than the estimations in the other two panels. When both measures of direct and indirect strategic alliances are included in one regression model, the statistical significance of the indirect strategic alliance measure disappears. One explanation of this result can be that listed companies are more transparent because they have much higher reporting and disclosure requirements. Hence, such deals do not need many certifications through third parties, for example, through direct or indirect alliances. Another result is that distance still matters, and the coefficient of the variable Same state is statistically significant at the 5 percent level.

To sum up, the results from Table 3 provide empirical support for Hypothesis 1a. Direct alliances might play an important role in the completion and success of M\&A deals because they are associated with a higher likelihood of an M\&A. In most estimations, this is also the case regarding indirect alliances. However, in the analysis in Panel C, where the target company is already a listed company, indirect strategic alliances do not have a statistically significant effect on the probability of an M\&A, and other effects might better explain the choice of the target and the success of an M\&A.

To test the next hypothesis, it is suitable to include interaction terms in an ordinary least squares (OLS) setting. Such an analysis allows me to estimate the relationship of the outcome of one independent variable on another independent variable. In this case, by the assumption of Hypothesis $1 \mathrm{~b}$, I would expect a negative and statistically significant coefficient of the interaction variable between direct and indirect alliances. Table 4 shows the results of OLS estimations with interaction terms between the variables for direct and indirect strategic alliances for Panels A, B, and C. The variables Dummy direct alliance, Dummy indirect alliance, and Number indirect alliances show statistically significant and positive coefficients in all settings. Furthermore, the interaction term between the variables Dummy direct alliance and Dummy indirect alliance are negative and statistically significant in Panels $\mathrm{B}$ and C (columns 3 and 5). The interaction term between Dummy direct alliance alliance and Number indirect alliances are negative and statistically significant in Panels A and B (columns 2 and 4). To sum up, these results show empirical evidence for Hypothesis $1 \mathrm{~b}$, which states that M\&A deals are more likely when only indirect or only direct ties are present, which is consistent with the results of Ahuja (2000).

In the next step, I analyze the influence of geographical distance on the probability of an M\&A. Table 5 shows OLS results with interaction effects. The underlying 
sample is Panel B, where the condition is that the target companies are US-based only. With such restriction, the bias resulting from cultural distances and differences between the companies can be mitigated to a certain extent. All estimations contain the variable Not same state, which serves as the reference category and indicates whether both companies are located in different US-states. The coefficient of this variable is negative and statistically significant in all settings, thus, showing a negative empirical relationship between geographical distance and the probability of an M\&A deal. Companies that are located in distant cities are more likely to have difficulties evaluating a potential target company than companies that are located near its headquarters. Table 5 shows that a larger geographical distance is associated with a lower likelihood of an M\&A. The coefficient of the variable Dummy both alliance is statistically not significant in column 1 and the interaction term between Dummy both alliance and Not same state is statistically not significant. However, when controlling for related alliances, the coefficient of the variable Dummy both alliance becomes statistically significant in all remaining specifications (columns 2-4). Furthermore, the interaction term between Dummy direct alliance and Not same state is statistically not significant (column 2). Finally, the interaction terms between Dummy indirect alliance and Not same state, and between Number indirect alliances and Not same state, are positive but statistically not significant. To sum up, there is not enough evidence for a clear relationship between related alliances and geographical distances, and no empirical evidence for a moderating effect of prior ties on geographical distance. Thus, Hypothesis 1c cannot be confirmed with this empirical analysis.

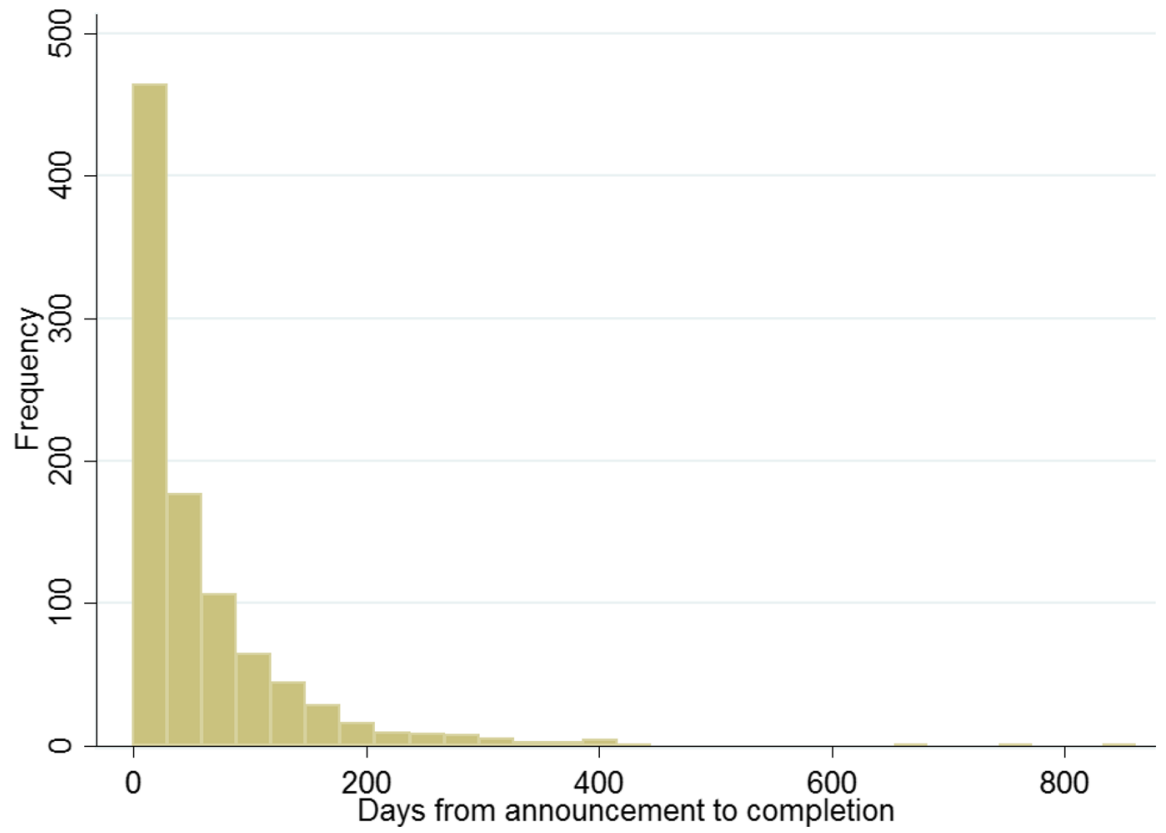

Fig. 3 Time to completion of an M\&A deal 
Table 6 Time to deal completion: poisson estimations (QML)

\begin{tabular}{|c|c|c|c|c|}
\hline DV: Time to completion & (1) & (2) & (3) & (4) \\
\hline Dummy both alliance & $\begin{array}{c}0.2588^{* *} \\
(0.1009)\end{array}$ & $\begin{array}{l}0.2129 * * \\
(0.1011)\end{array}$ & $\begin{array}{l}0.1983 * * \\
(0.1007)\end{array}$ & $\begin{array}{l}0.2309 * * \\
(0.1011)\end{array}$ \\
\hline Dummy direct alliance & $\begin{array}{l}-0.4230 \\
(0.2711)\end{array}$ & & & $\begin{array}{l}-0.6439 * * * \\
(0.2477)\end{array}$ \\
\hline Dummy indirect alliance & & $\begin{array}{l}0.0851 \\
(0.1677)\end{array}$ & & \\
\hline Number indirect alliances & & & $\begin{array}{l}0.0725 * * * \\
(0.0236)\end{array}$ & $\begin{array}{l}0.1115^{* * * *} \\
(0.0306)\end{array}$ \\
\hline Public target & $\begin{array}{l}0.7001 * * * \\
(0.1078)\end{array}$ & $\begin{array}{l}0.6979 * * * \\
(0.1078)\end{array}$ & $\begin{array}{l}0.6866 * * * \\
(0.1083)\end{array}$ & $\begin{array}{l}0.6852 * * * \\
(0.1079)\end{array}$ \\
\hline Hostile takeover & $\begin{array}{l}0.4116 \\
(0.4312)\end{array}$ & $\begin{array}{l}0.3606 \\
(0.4536)\end{array}$ & $\begin{array}{l}0.3293 \\
(0.4663)\end{array}$ & $\begin{array}{l}0.2953 \\
(0.4934)\end{array}$ \\
\hline Cross-border deal & $\begin{array}{l}0.0005 \\
(0.1234)\end{array}$ & $\begin{array}{l}0.0086 \\
(0.1236)\end{array}$ & $\begin{array}{l}0.0121 \\
(0.1237)\end{array}$ & $\begin{array}{l}0.0101 \\
(0.1239)\end{array}$ \\
\hline Payment (mix) & $\begin{array}{l}0.2319 \\
(0.1535)\end{array}$ & $\begin{array}{l}0.2536^{*} \\
(0.1508)\end{array}$ & $\begin{array}{l}0.2296 \\
(0.1532)\end{array}$ & $\begin{array}{l}0.1947 \\
(0.1535)\end{array}$ \\
\hline Payment (stock) & $\begin{array}{l}0.5050^{* * *} * \\
(0.1714)\end{array}$ & $\begin{array}{l}0.5316^{* * * *} \\
(0.1692)\end{array}$ & $\begin{array}{l}0.5328 * * * \\
(0.1687)\end{array}$ & $\begin{array}{l}0.4956^{* * * *} \\
(0.1699)\end{array}$ \\
\hline Payment (other) & $\begin{array}{l}-0.3478 * * \\
(0.1705)\end{array}$ & $\begin{array}{l}-0.3412 * * \\
(0.1714)\end{array}$ & $\begin{array}{l}-0.3458^{* *} \\
(0.1713)\end{array}$ & $\begin{array}{l}-0.3612^{* *} \\
(0.1709)\end{array}$ \\
\hline Divestiture & $\begin{array}{l}0.0081 \\
(0.2097)\end{array}$ & $\begin{array}{l}0.0235 \\
(0.2094)\end{array}$ & $\begin{array}{l}0.0316 \\
(0.2098)\end{array}$ & $\begin{array}{l}0.0190 \\
(0.2103)\end{array}$ \\
\hline Tender offer & $\begin{array}{l}-0.3391 * * \\
(0.1671)\end{array}$ & $\begin{array}{l}-0.3328 * * \\
(0.1674)\end{array}$ & $\begin{array}{l}-0.3208^{*} \\
(0.1649)\end{array}$ & $\begin{array}{l}-0.3456^{* *} \\
(0.1678)\end{array}$ \\
\hline Unsolicited & $\begin{array}{l}0.2881 \\
(0.4269)\end{array}$ & $\begin{array}{l}0.3008 \\
(0.4330)\end{array}$ & $\begin{array}{l}0.2463 \\
(0.4557)\end{array}$ & $\begin{array}{l}0.1867 \\
(0.4767)\end{array}$ \\
\hline Rumor & $\begin{array}{l}0.4586^{* * *} \\
(0.1845)\end{array}$ & $\begin{array}{l}0.4561 * * \\
(0.1884)\end{array}$ & $\begin{array}{l}0.4781 * * \\
(0.1923)\end{array}$ & $\begin{array}{l}0.4810^{* *} \\
(0.1932)\end{array}$ \\
\hline Year FE & Yes & Yes & Yes & Yes \\
\hline$N$ & 816 & 816 & 816 & 816 \\
\hline
\end{tabular}

This table shows the results of a Poisson estimation. The dependent variable is non-negative and it counts the days between the announcement and completion date of an M\&A deal. Dummy both alliance is a dummy variable that equals one if the acquirer and the target company had at least one strategic alliance (unrelated or related) prior to the M\&A deal, and zero otherwise. Dummy direct alliance is a dummy variable that equals one if the acquirer and the target company had a direct strategic alliance prior to the M\&A deal, and zero otherwise. Dummy indirect alliance is a dummy variable that equals one if the acquirer and the target company had an indirect strategic alliance prior to the M\&A deal, and zero otherwise. Number indirect alliances counts the number of indirect alliances between the acquirer and the target company. Public target is a dummy variable that equals one if the target was a listed company prior to the M\&A deal, and zero otherwise. Cross-border deal is a dummy variable that equals one if the target was a non-US company, and zero otherwise. Same state is a dummy variable that equals one if the acquirer and the target company were in the same US-state, and zero otherwise. Payment (Mix) is a dummy variable that equals one if the payment type is mix, and zero otherwise. Payment (Stock) is a dummy variable that equals one if the payment type is stock, and zero otherwise. Payment (Other) is a dummy variable that equals one if the payment type is other, and zero otherwise. Hostile takeover is a dummy variable that equals one if the deal is characterized as a hostile takeover, and zero otherwise. 
Table 6 (continued)

Divestiture is a dummy variable that equals one if the M\&A deal was a divestiture sale, and zero otherwise. Tender offer is a dummy variable that equals one if the acquirer offers its stock in the M\&A deal, and zero otherwise. Unsolicited is a dummy variable that equals one if the offer was unsolicited, and zero otherwise. Rumor is a dummy variable that equals one if the M\&A deal started as a rumor, and zero otherwise. A constant is included in all regressions. Robust standard errors are displayed in parentheses. *, $* *$, and $* * *$ indicate statistical significance at the $10 \%, 5 \%$, and $1 \%$ levels, respectively

\section{The time to a successful completion of an M\&A deal and the type of payment}

Figure 3 shows the distribution of the time between the announcement date and the completion date of an M\&A deal. Time is measured in days. The distribution is rightskewed with many deals that were completed on the announcement day.

Related alliances could reduce information asymmetries and increase the speed of information flows, thus reducing the time to completion of a deal. Given that the time to completion is always non-negative, it is reasonable to estimate the relationships by applying a count data model.

The conditional expectation of the number of days from announcement to completion $y$ is given by:

$$
E\left(y_{i} \mid \boldsymbol{x}_{i}\right)=\exp \left(\boldsymbol{x}_{i} \boldsymbol{\beta}\right)=\mu_{i},
$$

where $\mu$ is the mean parameter. This assumption of such a relationship between the mean and the regressors ensures that the expected number is non-negative. Furthermore, from the Poisson distribution and the parametrization of the relation between the mean and the regressors, the probability that $y$ takes on the value $h$, conditional on $\boldsymbol{x}$ is given by:

$$
P\left(y_{i}=h_{i} \mid \boldsymbol{x}_{i}\right)=\frac{\exp \left[-\exp \left(\boldsymbol{x}_{i} \boldsymbol{\beta}\right)\right]\left[\exp \left(\boldsymbol{x}_{i} \boldsymbol{\beta}\right)\right]^{h_{i}}}{h !} .
$$

The $\log$-likelihood function $\mathscr{L}$ for the observed sample with size $N$ is given by:

$$
\mathscr{L}(\boldsymbol{\beta})=\sum_{i=1}^{N}\left\{y_{i} \boldsymbol{x}_{i} \boldsymbol{\beta}-\exp \left(\boldsymbol{x}_{i} \boldsymbol{\beta}\right)-\log \left(y_{i} !\right)\right\}
$$

Maximizing the log-likelihood function with respect to $\beta$ yields the Poisson maximum likelihood estimation that is denoted as $\hat{\beta}_{P}$. The great advantage of the Poisson model is its consistency, even if the data is not distributed according to the Poisson distribution (Cameron and Trivedi 2005, p. 669). The important assumption is that the conditional mean $E\left(y_{i} \mid \boldsymbol{x}_{i}\right)$ is correctly specified. Such maximum likelihood estimations in case the density is misspecified, are called pseudo-maximum-likelihood or quasi-maximum-likelihood estimation. For the Poisson model, the $K$ non-linear equations that are the first-order conditions for the log-likelihood function are given by: 
Table 7 Time to deal completion: OLS estimations with interaction terms

\begin{tabular}{|c|c|c|c|c|}
\hline DV: Time to completion & (1) & (2) & (3) & (4) \\
\hline Dummy both alliance & $\begin{array}{l}0.8028 * * * \\
(0.1402)\end{array}$ & $\begin{array}{l}0.6687 * * * \\
(0.1478)\end{array}$ & $\begin{array}{l}0.8273 * * * \\
(0.1402)\end{array}$ & $\begin{array}{l}0.7001 * * * \\
(0.1475)\end{array}$ \\
\hline Dummy direct alliance & $\begin{array}{l}-0.8128 \\
(0.6103)\end{array}$ & & $\begin{array}{l}-0.9348^{*} \\
(0.5659)\end{array}$ & \\
\hline Dummy indirect alliance & & $\begin{array}{l}1.5367 * * * \\
(0.3203)\end{array}$ & & $\begin{array}{l}-0.5331 \\
(0.4649)\end{array}$ \\
\hline Dummy direct alliance & -0.8429 & & & \\
\hline $\mathrm{x}$ Public target & $(0.9044)$ & & & \\
\hline Dummy indirect alliance & & $-2.1419 * * *$ & & \\
\hline $\mathrm{x}$ Public target & & $(0.4076)$ & & \\
\hline Dummy direct alliance & & & $1.2367 *$ & \\
\hline x Payment (mix) & & & $(0.6564)$ & \\
\hline Dummy direct alliance & & & $-4.1157 * * *$ & \\
\hline x Payment (stock) & & & $(0.6449)$ & \\
\hline Dummy direct alliance & & & -0.8137 & \\
\hline x Payment (other) & & & $(1.0033)$ & \\
\hline Dummy indirect alliance & & & & $0.9067^{*}$ \\
\hline x Payment (mix) & & & & $(0.5118)$ \\
\hline Dummy indirect alliance & & & & 0.7046 \\
\hline x Payment (stock) & & & & $(0.5943)$ \\
\hline Dummy indirect alliance & & & & -0.2763 \\
\hline x Payment (other) & & & & $(1.3166)$ \\
\hline Public target & $\begin{array}{l}1.5972 * * * \\
(0.1437)\end{array}$ & $\begin{array}{l}1.6593 * * * \\
(0.1471)\end{array}$ & $\begin{array}{l}1.5679 * * * \\
(0.1459)\end{array}$ & $\begin{array}{l}1.5655 * * * \\
(0.1513)\end{array}$ \\
\hline Payment (mix) & $\begin{array}{l}0.3130 \\
(0.2007)\end{array}$ & $\begin{array}{l}0.3771^{*} \\
(0.2022)\end{array}$ & $\begin{array}{l}0.3114 \\
(0.2009)\end{array}$ & $\begin{array}{l}0.3382 * \\
(0.2044)\end{array}$ \\
\hline Payment (stock) & $\begin{array}{l}0.4805^{* *} \\
(0.1889)\end{array}$ & $\begin{array}{l}0.5315 * * * \\
(0.1917)\end{array}$ & $\begin{array}{l}0.5154 * * * \\
(0.1882)\end{array}$ & $\begin{array}{l}0.5267 * * * \\
(0.1952)\end{array}$ \\
\hline Payment (other) & $\begin{array}{l}-0.9953 \text { *** } \\
(0.1751)\end{array}$ & $\begin{array}{l}-0.9595^{* * *} \\
(0.1776)\end{array}$ & $\begin{array}{l}-0.9694 * * * \\
(0.1767)\end{array}$ & $\begin{array}{l}-0.9796^{* * * *} \\
(0.1781)\end{array}$ \\
\hline Controls & Yes & Yes & Yes & Yes \\
\hline$N$ & 816 & 816 & 816 & 816 \\
\hline
\end{tabular}

This table shows results of OLS estimations. The dependent variable is non-negative and it counts the days between the announcement and completion date of an M\&A deal. Dummy direct alliance is a dummy variable that equals one if the acquirer and the target company had a direct strategic alliance prior to the M\&A deal, and zero otherwise. Dummy indirect alliance is a dummy variable that equals one if the acquirer and the target company had an indirect strategic alliance prior to the M\&A deal, and zero otherwise. Number indirect alliances counts the number of indirect alliances between the acquirer and the target company. Public target is a dummy variable that equals one if the target was a listed company prior to the M\&A deal, and zero otherwise. Payment (Mix) is a dummy variable that equals one if the payment type is mix, and zero otherwise. Payment (Stock) is a dummy variable that equals one if the payment type is stock, and zero otherwise. Payment (Other) is a dummy variable that equals one if the payment type is other, and zero otherwise. A constant is included in all regressions. Robust standard errors are displayed in parentheses. *, **, and *** indicate statistical significance at the $10 \%, 5 \%$, and $1 \%$ levels, respectively 


$$
\sum_{i=1}^{N} \boldsymbol{x}_{i}^{\prime}\left[y_{i}-\exp \left(\boldsymbol{x}_{\boldsymbol{i}} \hat{\boldsymbol{\beta}}\right)\right]=0 .
$$

If the conditional mean is correctly specified, that is, $E\left(y_{i} \mid \boldsymbol{x}_{i}\right)=\exp \left(\boldsymbol{x}_{i} \boldsymbol{\beta}\right)$, and a constant is included in $\boldsymbol{x}$, the summation on the left-hand-side of Eq. 4 has expectation zero, and hence, the Poisson pseudo-maximum-likelihood is consistent. The variance-covariance matrix is given by the negative inverse of the second derivative of the log-likelihood function.

By taking the log of Eq. 1, the estimated coefficients can be directly interpreted. Because the first derivative is:

$$
\frac{\partial \log \left[E\left(y_{i} \mid x_{i}\right)\right]}{\partial x_{j}}=\beta_{j},
$$

the semi-elasticity of $E\left(y_{i} \mid \boldsymbol{x}_{i}\right)$ with respect to $x_{j}$ is given by $100 \beta_{j}$.

Table 6 shows the results of the quasi-maximum-likelihood estimation. All the estimations contain the variable Dummy both alliance, which serves as the reference category. Controlling for direct alliances by the variable Dummy direct alliance shows that the coefficient is negative but statistically not significant (column 1). Further, the coefficient of the variable Dummy indirect alliance is positive but statistically not significant (column 2). In estimation (3), the effect of the number of indirect alliances is statistically significant and positive, thus, indicating that indirect alliances are positively related to the number of days between announcement and completion. However, in estimation (4) of Table 6, both measures (direct and indirect alliances) are included in the estimation, and the coefficient of the variable Dummy direct alliance becomes statistically significant. Therefore, a direct alliance between the acquirer and the target company is associated with a $64 \%$ decrease in the expected number of days between announcement and completion of an M\&A deal, compared to the reference category. This could indicate that direct alliances become more valuable when there are ties through indirect alliances also. Another explanation could be that a deep connectedness of the target company can be beneficial in the transaction process. However, Hypothesis 2a is only confirmed for deals with prior ties through direct alliances.

Furthermore, the coefficient of the dummy variable that measures whether the target company was a listed company is positive and statistically significant. In most cases, the transaction process of acquiring a listed company is more complicated than a private target because more people and decision-makers are involved in the process. Moreover, the M\&A deal must be approved by the shareholders. Another explanation for this effect could be that listed companies are obligated to announce such important events as soon as possible, whereas, the announcement of an acquiring process of a private target can be held back for a more extended period.

Another important result is the type of payment. In all the estimations, the reference category is cash payment. Stock payment is associated with a longer time period from announcement to completion, while other payment is associated with a decrease in the time between announcement and completion, compared to the reference category. 
Table 8 Cash vs. stock payment: logit estimations

\begin{tabular}{|c|c|c|c|c|}
\hline DV: Cash (0) vs. stock (1) payment & (1) & (2) & (3) & (4) \\
\hline Dummy both alliance & $\begin{array}{l}0.0376 \\
(0.0507)\end{array}$ & $\begin{array}{l}-0.0241 \\
(0.0536)\end{array}$ & $\begin{array}{l}-0.0162 \\
(0.0528)\end{array}$ & $\begin{array}{l}0.1741 \\
(0.2640)\end{array}$ \\
\hline Dummy direct alliance & $\begin{array}{l}-0.2875^{* * *} \\
(0.0287)\end{array}$ & & & $\begin{array}{l}-3.4488 * * * \\
(1.1492)\end{array}$ \\
\hline Dummy indirect alliance & & $\begin{array}{l}0.0506 \\
(0.1197)\end{array}$ & & \\
\hline Number indirect alliances & & & $\begin{array}{l}-0.0002 \\
(0.0571)\end{array}$ & $\begin{array}{l}0.0633 \\
(0.2868)\end{array}$ \\
\hline Public target & $\begin{array}{l}0.1124 * \\
(0.0624)\end{array}$ & $\begin{array}{l}0.0941 \\
(0.0614)\end{array}$ & $\begin{array}{l}0.0940 \\
(0.0613)\end{array}$ & $\begin{array}{l}0.5426^{*} \\
(0.2895)\end{array}$ \\
\hline Hostile takevoer & $\begin{array}{l}0.7327 * * * \\
(0.0240)\end{array}$ & $\begin{array}{l}0.7208 * * * \\
(0.0233)\end{array}$ & $\begin{array}{l}0.7210 * * * \\
(0.0234)\end{array}$ & $\begin{array}{l}10.9815^{* * * *} \\
(1.1574)\end{array}$ \\
\hline Cross-border deal & $\begin{array}{l}-0.1762 * * * \\
(0.0428)\end{array}$ & $\begin{array}{l}-0.1786^{* * * *} \\
(0.0438)\end{array}$ & $\begin{array}{l}-0.1795^{* * * *} \\
(0.0437)\end{array}$ & $\begin{array}{l}-1.0405 * * * \\
(0.3071)\end{array}$ \\
\hline Divestiture & $\begin{array}{l}-0.2555^{* * *} \\
(0.0403)\end{array}$ & $\begin{array}{l}-0.2567 * * * \\
(0.0493)\end{array}$ & $\begin{array}{l}-0.2548 * * * \\
(0.0498)\end{array}$ & $\begin{array}{l}-2.5907 * * \\
(1.1587)\end{array}$ \\
\hline Tender offer & $\begin{array}{l}-0.3360 * * * \\
(0.0288)\end{array}$ & $\begin{array}{l}-0.3401 * * * \\
(0.0295)\end{array}$ & $\begin{array}{l}-0.3393 * * * \\
(0.0297)\end{array}$ & $\begin{array}{l}-3.5437 * * * \\
(0.7359)\end{array}$ \\
\hline Unsolicited & $\begin{array}{l}-0.2991 * * * \\
(0.0267)\end{array}$ & $\begin{array}{l}-0.3100^{* * * *} \\
(0.0258)\end{array}$ & $\begin{array}{l}-0.3098 * * * \\
(0.0259)\end{array}$ & $\begin{array}{l}-10.6606^{* * *} \\
(0.9692)\end{array}$ \\
\hline Rumor & $\begin{array}{l}-0.0942 \\
(0.0902)\end{array}$ & $\begin{array}{l}-0.1094 \\
(0.0998)\end{array}$ & $\begin{array}{l}-0.1130 \\
(0.0990)\end{array}$ & $\begin{array}{l}-0.5278 \\
(0.5919)\end{array}$ \\
\hline Year FE & Yes & Yes & Yes & Yes \\
\hline$N$ & 545 & 545 & 545 & 545 \\
\hline
\end{tabular}

This table shows partial effects at the averages (PEA) of logistic regressions. The dependent variable is a dummy variable that equals one if the type of payment in the M\&A deal was stocks, and zero if the type of payment was cash. Dummy both alliance is a dummy variable that equals one if the acquirer and the target company had at least one strategic alliance (unrelated or related) prior to the M\&A deal, and zero otherwise. Dummy direct alliance is a dummy variable that equals one if the acquirer and the target company had a direct strategic alliance prior to the M\&A deal, and zero otherwise. Dummy indirect alliance is a dummy variable that equals one if the acquirer and the target company had an indirect strategic alliance prior to the M\&A deal, and zero otherwise. Number indirect alliances counts the number of indirect alliances between the acquirer and the target company. Public target is a dummy variable that equals one if the target was a listed company prior to the M\&A deal, and zero otherwise. Hostile takeover is a dummy variable that equals one if the deal is characterized as a hostile takeover, and zero otherwise. Cross-border deal is a dummy variable that equals one if the target was a non-US company, and zero otherwise. Divestiture is a dummy variable that equals one if the M\&A deal was a divestiture sale, and zero otherwise. Tender offer is a dummy variable that equals one if the acquirer offers its stock in the M\&A deal, and zero otherwise. Unsolicited is a dummy variable that equals one if the offer was unsolicited, and zero otherwise. Rumor is a dummy variable that equals one if the M\&A deal started as a rumor, and zero otherwise. A constant is included in all regressions. Robust standard errors are displayed in parentheses. $*, * *$, and $* * *$ indicate statistical significance at the $10 \%, 5 \%$, and $1 \%$ levels, respectively 
Table 9 Post-M\&A performance: OLS estimations

\begin{tabular}{|c|c|c|c|c|}
\hline $\mathrm{DV}: \Delta R O A_{(t+3) /(t-1)}$ & (1) & (2) & (3) & (4) \\
\hline Dummy both alliance & $\begin{array}{l}0.8497 \\
(0.7449)\end{array}$ & $\begin{array}{l}0.8680 \\
(0.7138)\end{array}$ & $\begin{array}{l}0.7938 \\
(0.6994)\end{array}$ & $\begin{array}{l}0.7910 \\
(0.7255)\end{array}$ \\
\hline Dummy direct alliance & $\begin{array}{l}0.2028 \\
(1.3862)\end{array}$ & & & $\begin{array}{l}0.0262 \\
(1.4640)\end{array}$ \\
\hline Dummy indirect alliance & & $\begin{array}{l}0.0402 \\
(1.0380)\end{array}$ & & \\
\hline Number indirect alliances & & & $\begin{array}{l}0.2086 \\
(0.2932)\end{array}$ & $\begin{array}{l}0.2074 \\
(0.3162)\end{array}$ \\
\hline ublic target & $\begin{array}{l}1.0072 \\
(1.3247)\end{array}$ & $\begin{array}{l}1.0054 \\
(1.3171)\end{array}$ & $\begin{array}{l}0.9588 \\
(1.2894)\end{array}$ & $\begin{array}{l}0.9592 \\
(1.2828)\end{array}$ \\
\hline Hostile takeover & $\begin{array}{l}-0.9751 \\
(1.9415)\end{array}$ & $\begin{array}{l}-0.9985 \\
(2.1420)\end{array}$ & $\begin{array}{l}-1.3186 \\
(1.9942)\end{array}$ & $\begin{array}{l}-1.3170 \\
(2.0218)\end{array}$ \\
\hline Cross-border deal & $\begin{array}{l}0.9454 \\
(1.4066)\end{array}$ & $\begin{array}{l}0.9463 \\
(1.4141)\end{array}$ & $\begin{array}{l}0.9512 \\
(1.4120)\end{array}$ & $\begin{array}{l}0.9511 \\
(1.4144)\end{array}$ \\
\hline ayment ( $\mathrm{n}$ & $\begin{array}{c}-5.9675 \\
(5.0003)\end{array}$ & $\begin{array}{l}-5.9770 \\
(5.0031)\end{array}$ & $\begin{array}{l}-6.0333 \\
(5.0556)\end{array}$ & $\begin{array}{l}-6.0319 \\
(5.0831)\end{array}$ \\
\hline Payment (stock) & $\begin{array}{l}-0.4176 \\
(1.9780)\end{array}$ & $\begin{array}{l}-0.4344 \\
(1.9505)\end{array}$ & $\begin{array}{l}-0.4304 \\
(1.9602)\end{array}$ & $\begin{array}{l}-0.4283 \\
(1.9716)\end{array}$ \\
\hline Payment (other) & $\begin{array}{l}0.8593 \\
(0.7566)\end{array}$ & $\begin{array}{l}0.8546 \\
(0.7566)\end{array}$ & $\begin{array}{l}0.8292 \\
(0.7488)\end{array}$ & $\begin{array}{l}0.8298 \\
(0.7502)\end{array}$ \\
\hline Divestiture & $\begin{array}{l}1.2547 \\
(1.4355)\end{array}$ & $\begin{array}{l}1.2497 \\
(1.4486)\end{array}$ & $\begin{array}{l}1.2590 \\
(1.4604)\end{array}$ & $\begin{array}{l}1.2598 \\
(1.4561)\end{array}$ \\
\hline Tender offer & $\begin{array}{l}-0.5874 \\
(1.0867)\end{array}$ & $\begin{array}{l}-0.5965 \\
(1.0919)\end{array}$ & $\begin{array}{l}-0.5877 \\
(1.0786)\end{array}$ & $\begin{array}{l}-0.5871 \\
(1.0875)\end{array}$ \\
\hline Unsolicited & $\begin{array}{l}-0.8741 \\
(2.4945)\end{array}$ & $\begin{array}{l}-0.9004 \\
(2.5321)\end{array}$ & $\begin{array}{l}-1.0618 \\
(2.5888)\end{array}$ & $\begin{array}{l}-1.0581 \\
(2.6144)\end{array}$ \\
\hline Rumor & $\begin{array}{l}3.7680 \\
(3.0226)\end{array}$ & $\begin{array}{l}3.7686 \\
(3.0271)\end{array}$ & $\begin{array}{l}3.8274 \\
(3.0694)\end{array}$ & $\begin{array}{l}3.8272 \\
(3.0767)\end{array}$ \\
\hline Year FE & Yes & Yes & Yes & Yes \\
\hline$N$ & 485 & 485 & 485 & 485 \\
\hline
\end{tabular}

This table shows results of OLS estimations. The dependent variable is the difference between the return on assets (ROA) three years after and one year before the focal acquisition. Dummy both alliance is a dummy variable that equals one if the acquirer and the target company had at least one strategic alliance (unrelated or related) prior to the M\&A deal, and zero otherwise. Dummy direct alliance is a dummy variable that equals one if the acquirer and the target company had a direct strategic alliance prior to the M\&A deal, and zero otherwise. Dummy indirect alliance is a dummy variable that equals one if the acquirer and the target company had an indirect strategic alliance prior to the M\&A deal, and zero otherwise. Number indirect alliances counts the number of indirect alliances between the acquirer and the target company. Public target is a dummy variable that equals one if the target was a listed company prior to the M\&A deal, and zero otherwise. Hostile takeover is a dummy variable that equals one if the deal is characterized as a hostile takeover, and zero 
Table 9 (continued)

otherwise. Cross-border deal is a dummy variable that equals one if the target was a non-US company, and zero otherwise. Payment (Mix) is a dummy variable that equals one if the payment type is mix, and zero otherwise. Payment (Stock) is a dummy variable that equals one if the payment type is stock, and zero otherwise. Payment (Other) is a dummy variable that equals one if the payment type is other, and zero otherwise. Divestiture is a dummy variable that equals one if the M\&A deal was a divestiture sale, and zero otherwise. Tender offer is a dummy variable that equals one if the acquirer offers its stock in the M\&A deal, and zero otherwise. Unsolicited is a dummy variable that equals one if the offer was unsolicited, and zero otherwise. Rumor is a dummy variable that equals one if the M\&A deal started as a rumor, and zero otherwise. A constant is included in all regressions. Robust standard errors are displayed in parentheses. *, **, and $* * *$ indicate statistical significance at the $10 \%, 5 \%$, and $1 \%$ levels, respectively

In the next step, I examine the various interaction effects between the different alliance ties and other important control variables. Table 7 shows the results of OLS estimations with interaction terms. Public targets are associated with a longer deal transaction process because the coefficient of the variable Public target is positive and statistically significant (columns 1-4). However, prior-related alliances should be beneficial because direct or indirect alliances can be an indicator for trust between both companies, given that they are in a business relationship (direct alliance), or they share common strategic partners (indirect alliances). Furthermore, the interaction term shows that the expected number of days between announcement and completion decreases when there are prior ties through indirect alliances (column 2). Prior indirect ties and the acquisition of a public target are associated with a shorter time from announcement to acquisition. This result indicates the importance of the connectedness of the target companies. A well-connected target company is also known to more shareholders, and thus, could decrease the time of the shareholder approval process. The coefficient is statistically significant at the $1 \%$ level. However, although the coefficient of the interaction term between Dummy direct alliance and Public target is also negative, it is statistically not significant (column 1). The results confirm Hypothesis $2 \mathrm{~b}$ only for deals with prior ties through indirect alliances.

The type of payment for the acquisition is an important factor that influences the time to completion. Table 6 showed that in cases where the payment type is stock, the time to completion significantly increases by around $50 \%$, compared to cash payment. However, the outcome of the type of payment is also related to prior alliance ties. If prior ties induce trust between the acquirer and the target company, the shareholders could be more willing to accept the payment type stock, which is associated with an increase in capital. The estimations show that the coefficient of the variable Payment (stock) is positive and significant, which implies that the time to completion is longer. However, this result must be interpreted with caution because an interaction term is included in the estimation. Therefore, this result is only valid when there are no prior direct alliances. If there are prior direct alliances, then the overall effect is negative, hence, a shorter time to completion, because the coefficient of the interaction term between the payment type stock and a prior direct alliance is 


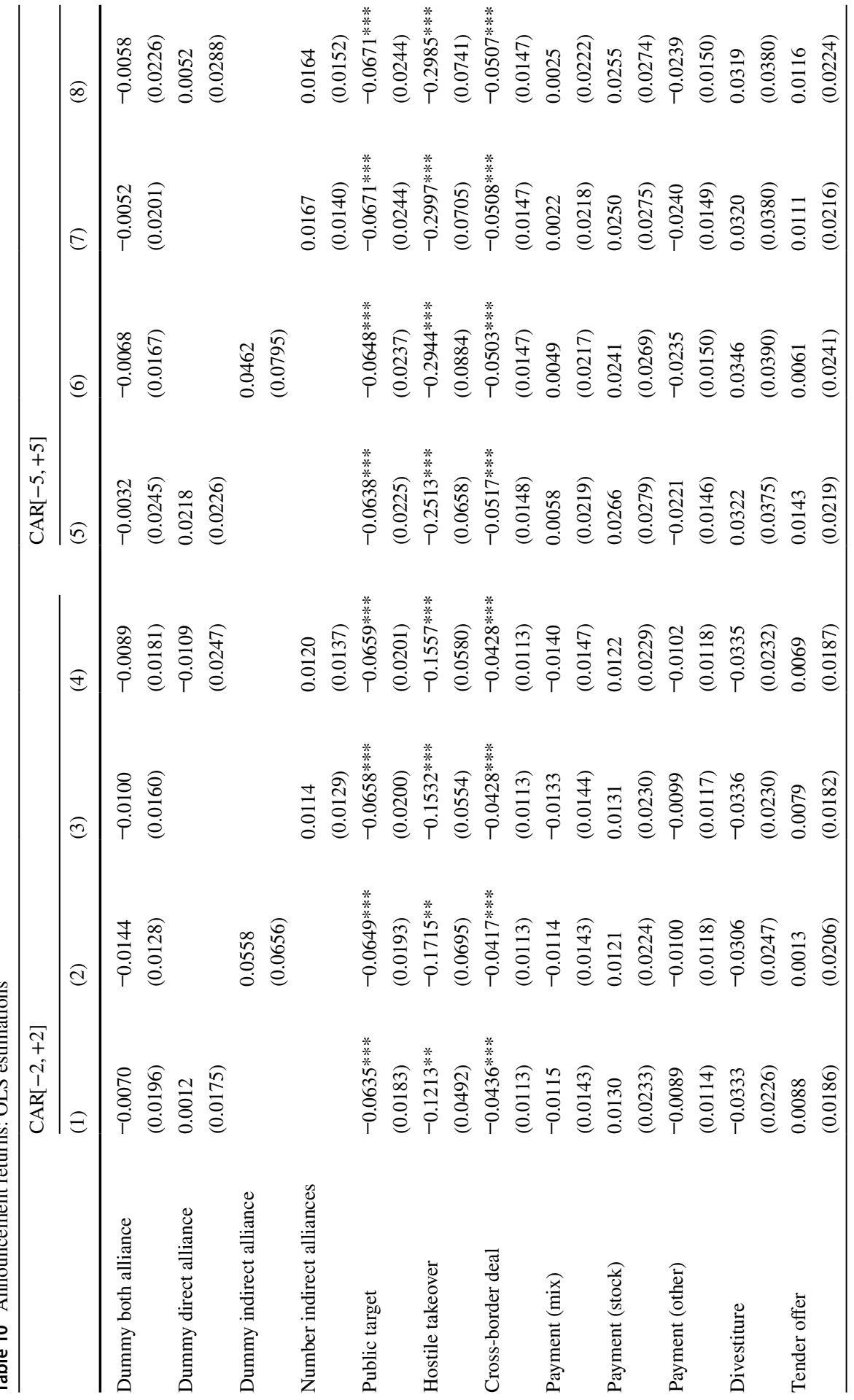




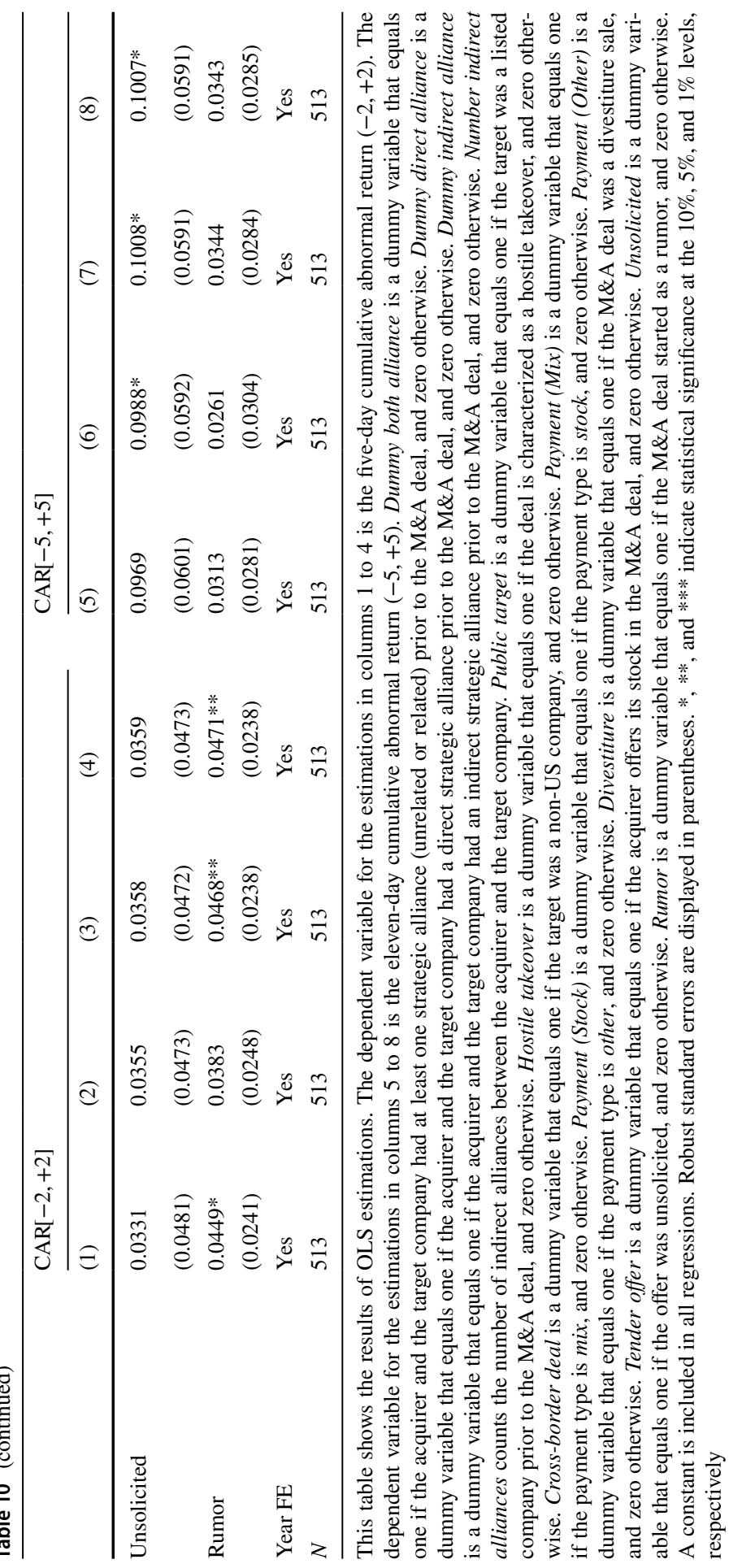


negative and statistically significant (column 3). Prior direct ties can decrease the time to completion for deals with stock payment. Indirect alliances and the payment type mix are associated with an increase in the time to completion (column 4). Hypothesis $2 \mathrm{c}$ is only confirmed for deals with prior ties through direct alliances.

Regarding the choice between the payment type cash and stock, Table 8 shows the results of logistic regressions, where the dependent variable equals one if the type of payment was stock, and zero if the type of payment was cash. The main result is that the presence of prior ties through direct strategic alliances is associated with a higher likelihood of cash payment compared to stock payments (columns 1 and 4). In estimations (2) to (4), the coefficients of the variables that measure prior ties through indirect alliances are statistically not significant, and thus, are not associated with the choice of the type of payment.

\section{The role of related alliances on post-M\&A performance and announcement returns}

Table 9 presents the results of the first analysis, which focused on the role of related alliances on post-M\&A performance. The dependent variable is a measure of the return on assets and is calculated as the difference between the return on assets 3 years after and 1 year before the focal acquisition. This measure is a common measure for M\&A performance in the literature (see, e.g., Cho and Arthurs 2018; Healy et al. 1992; Zollo and Reuer 2010).

The OLS estimations indicate no statistically significant relationship between the return on assets and related strategic alliances. Throughout all the estimations and settings, the coefficients of the variables that indicate prior ties are positive but not significant. In addition, the coefficients of the control variables are all statistically significant.

Table 10 shows OLS estimations, where the dependent variable is a calculation of CARs using the market model. Columns 1 to 4 show the results of the event study, where the event window is -2 and +2 around the announcement day of the deal (in $\%)$. Besides, I run regressions with a wider event window $(-5,+5)$. The estimation period for all regression is -300 and -91 days. The effects of related alliances on CARs are positive; however, the coefficients are statistically not significant. Other control variables, such as Public target, Hostile takeover, or Cross-border deal do have a statistically significant negative effect on CARs around the announcement date of the deal.

To sum up, with this empirical setting, it cannot be shown that there is a significant relationship between the presence of prior ties through strategic alliances and post-M\&A performance measures, such as return on assets, or CARs around the announcement date of the deal. Thus, Hypothesis $3 \mathrm{a}$ and $3 \mathrm{~b}$ cannot be confirmed with these empirical results. 


\section{Discussion and limitations}

The main results of the first part of the empirical analyses show that there is a significant relationship between the likelihood of an M\&A and prior ties through related strategic alliances. There are several explanations for the underlying results. First, access to private information can have a positive effect on the valuation and selection of a potential target, as uncertainties about a future target, and thus, transaction costs can be reduced. Hence, prior ties can lead to a more efficient acquirer-targetmatching and a better fit between both companies. Furthermore, the embeddedness in a network can explain the choice of the future target. Prior ties through direct alliances enhance trust between both parties, and indirect alliances serve as a certification or quality signal. If a common strategic partner was shared between the acquirer and target company, it can serve as a certification for good quality through a third party.

Regarding the role of related alliances in the time to completion of an M\&A deal, the results are not clear-cut. At first glance, direct alliances do not have a statistically significant effect on the time to completion of an M\&A. Indirect alliances even seem to increase the time from announcement to completion, thus increasing the time of the transaction process. However, when analyzing the relationships in more detail, other vital results emerge. For example, when including both measures of related alliances, the effect of direct alliances becomes significant. Furthermore, indirect alliances might play an important role in the acquisition of a public target because they can reduce the time of the transaction process owing to a familiar relationship between the acquirer and the target company. Moreover, when it comes to the type of payment, indirect alliances might be beneficial when the acquisition is paid by stocks. One explanation can be that the reputation of a well-connected target company might increase the speed of approval by the board of directors and shareholders, as the target company is well-known.

The final empirical analysis of this study examines the role of related alliances on post-M\&A performance. First, the analysis shows that there is no statistically significant link between related alliances and M\&A performance. The M\&A performance is measured by the difference between the return on assets three years after and one year before the focal acquisition. The result is supported by previous empirical studies, for example, by Cho and Arthurs (2018), who also do not find any significant effect of alliances on post-M\&A return on assets. Second, the findings in this study do not show a statistically significant difference between announcement returns of deals with and without related alliances. One explanation can be that the effects of any strategic alliance are already priced into the stock before the M\&A announcement.

The challenge of this study is the empirical setting and the establishment of a causal link between related alliances and M\&As. Different counterfactual samples were built to eliminate or reduce some of the unobservable factors. The estimations with different counterfactual samples show similar results. Furthermore, the relationship between related alliances and the likelihood of M\&As seem to be robust. Nevertheless, there might be concerns about the creation of the 
counterfactuals. I built different counterfactuals to reduce bias risks. However, there are also other possible ways of constructing the samples, for example, by random matching.

The empirical analyses in this study are subject to various limitations. One of the potential problems is self-selection by companies. Target companies with better quality or a more promising future might choose related alliances to signal sound quality. Therefore, the higher probability of an M\&A for companies with prior ties can also be explained by self-selection. However, since the characteristics of a promising future, such as the talent of the entrepreneur of the target company, are often not observable, the empirical results are subject to bias. In addition, as information asymmetries are present between the buyer and seller, the results, as well as the causal link between the probability of an M\&A and related alliances, must be interpreted with caution. The solutions to these issues might be to use other empirical methods, such as instrumental variable regressions or propensity score matching, which can reduce the bias to a certain amount.

Another potential bias can be the similarity of both companies. An M\&A between two companies might be more likely when the two companies are similar or share a common or suitable corporate strategy, and thus, make a good fit. This can be a driving factor of the selection into an M\&A, rather than prior ties through related alliances. However, such empirical shortcomings are often challenging to overcome, as many factors are unobservable.

The last part of the empirical analyses is affected by technical shortcomings. There is no consensus in the extant literature about the best way to measure M\&A performance (see, e.g., King et al. 2004). Measuring the effect of post-M\&A performance by the difference between the return on assets 3 years after and 1 year before the focal acquisition might be subject to bias, as the accounting of the assets after the acquisition might already include the assets of the target company. Finally, the event study method is also vulnerable to confounding conditions.

\section{Conclusion}

The role of strategic alliances before M\&As is not straightforward. This study showed that in some ways, not only direct but also indirect alliances play an important role in the M\&A transaction process. The empirical results confirm some of the hypotheses that alliances can enhance the efficiency of target selection and decrease transaction costs. However, one has to distinguish between different types of prior ties, as not only direct ties but also indirect ties can affect the outcome of an M\&A. The results have importance from a practical perspective also. Prior ties through strategic alliances can be a good predictor for the outcome of the M\&A and the time of the transaction process. Managers from acquiring companies can use their network of strategic alliances to find future potential target companies. Moreover, entrepreneurs of target companies can use the information that they acquire through related alliances. 
Future research studies could extend this analysis in several ways. For example, future studies could expand the sample and include deals from other countries and different industries. In addition, the analysis could be extended to higher grades of prior ties. The effect of prior ties might decrease with higher grades of connections. Furthermore, as the construction of the counterfactuals is one of the main challenges in such empirical analysis, it would be worthwhile to extend the number of counterfactual samples. For example, one way would be to randomly select potential targets to actual deals. Another approach would be to restrict the pool of potential targets using several factors, such as industry, age, and other company characteristics. Moreover, an interesting way would be to match peers or competitors of the actual target as potential targets. However, this method would be subject to data availability issues because most of the target companies are privately held.

Finally, the way of identification of the causal link could be improved by applying other empirical methods and research designs, such as instrumental variable regressions or company survey analysis. Yet, the first method will need valid instruments, and the second method a sufficient number of observations.

Funding Open Access funding enabled and organized by Projekt DEAL. During this study, the author received a salary by the University of Hohenheim. I am grateful for the access to databases provided by DALAHO, University of Hohenheim.

\section{Declarations}

Conflict of interest The author declares that he has no conflict of interest. The data that support the findings of this study are available from Thomson SDC Platinum, but restrictions apply to the availability of these data, which were used under license for the current study, and so are not publicly available. Data are however available from the authors upon reasonable request and with permission of Thomson Reuters.

Ethical approval The author complies with ethical standards.

Informed consent This study did not involve human participants and no animals were involved.

Open Access This article is licensed under a Creative Commons Attribution 4.0 International License, which permits use, sharing, adaptation, distribution and reproduction in any medium or format, as long as you give appropriate credit to the original author(s) and the source, provide a link to the Creative Commons licence, and indicate if changes were made. The images or other third party material in this article are included in the article's Creative Commons licence, unless indicated otherwise in a credit line to the material. If material is not included in the article's Creative Commons licence and your intended use is not permitted by statutory regulation or exceeds the permitted use, you will need to obtain permission directly from the copyright holder. To view a copy of this licence, visit http://creativecommons.org/licen ses/by/4.0/.

\section{References}

Ahuja G (2000) Collaboration networks, structural holes, and innovation: a longitudinal study. Adm Sci Q 45:425-455

Bauer F, Matzler K (2014) Antecedents of M\&A success: The role of strategic complementarity, cultural fit, and degree and speed of integration. Strateg Manag J 35:269-291 
Burt RS (2009) Structural holes: the social structure of competition. Harvard University Press, Cambridge Cai Y, Sevilir M (2012) Board connections and M\&A transactions. J Financ Econ 103:327-349

Cameron AC, Trivedi PK (2005) Microeconometrics: methods and applications. Cambridge University Press, Cambridge

Capron L, Shen J-C (2007) Acquisitions of private vs. public firms: private information, target selection, and acquirer returns. Strateg Manag J 28:891-911

Chakrabarti A, Mitchell W (2013) The persistent effect of geographic distance in acquisition target selection. Org Sci 24:1805-1826

Chakrabarti A, Mitchell W (2016) The role of geographic distance in completing related acquisitions: evidence from US. chemical manufacturers. Strateg Manag J 37:673-694

Chang S-C, Tsai M-T (2013) The effect of prior alliance experience on acquisition performance. Appl Econ 45:765-773

Cho SY, Arthurs JD (2018) The influence of alliance experience on acquisition premiums and post-acquisition performance. J Bus Res 88:1-10

Cohen WM, Levinthal DA (1990) Absorptive capacity: a new perspective on learning and innovation, Administrative Sci Q 128-152

Coval JD, Moskowitz TJ (1999) Home bias at home: local equity preference in domestic portfolios. J Financ 54:2045-2073

Cuypers IR, Cuypers Y, Martin X (2017) When the target may know better: effects of experience and information asymmetries on value from mergers and acquisitions. Strateg Manag J 38:609-625

Diestre L, Rajagopalan N (2012) Are all 'sharks' dangerous? New biotechnology ventures and partner selection in R\&D alliances, Strateg Manag J 33:1115-1134

Fang Y, Jin D, Sun X, Wang H (2015) New evidence on alliance experience and acquisition performance: Short-run pain, long-run gain? Stud Econ Financ 32:53-73

Gulati R (1995) Does familiarity breed trust? The implications of repeated ties for contractual choice in alliances. Acad Manag J 38:85-112

Gulati R (1995b): Social structure and alliance formation patterns: a longitudinal analysis. Administrative Sci Q 619-652

Gulati R (1998) Alliances and networks. Strateg Manag J 19:293-317

Gulati R (1999) Network location and learning: the influence of network resources and firm capabilities on alliance formation. Strateg Manag J 20:397-420

Gulati R, Lavie D, Singh H (2009) The nature of partnering experience and the gains from alliances. Strateg Manag J 30:1213-1233

Hagedoorn J, Sadowski B (1999) The transition from strategic technology alliances to mergers and acquisitions: an exploratory study. J Manag Stud 36:87-107

Harford J, Schonlau R, Stanfield J (2019) Trade relationships, indirect economic links, and mergers. Manag Sci 65:3085-3110

He,Z, Yu H, Du L (2018) Cohabitation before marriage: Do prior alliances enhance post-merger performance? Rev Quantitative Financ Account, 1-35

Healy PM, Palepu KG, Ruback RS (1992) Does corporate performance improve after mergers? J Financ Econ 31:135-175

Higgins MJ, Rodriguez D (2006) The outsourcing of R\&D through acquisitions in the pharmaceutical industry. J Financ Econ 80:351-383

Hoenig D, Henkel J (2015) Quality signals? The role of patents, alliances, and team experience in venture capital financing. Res Policy 44:1049-1064

King DR, Dalton DR, Daily CM, Covin JG (2004) Meta-analyses of post-acquisition performance: indications of unidentified moderators. Strateg Manag J 25:187-200

Megginson WL, Weiss KA (1991) Venture capitalist certification in initial public offerings. J Financ 46:879-903

Porrini P (2004) Alliance experience and value creation in high-tech and low-tech acquisitions. J High Technol Manag Res 15:267-292

Raub W, Weesie J (1990) Reputation and efficiency in social interactions: an example of network effects. Am J Sociol 96:626-654

Reuer JJ, Ragozzino R (2008) Adverse selection and M\&A design: the roles of alliances and IPOs. J Econ Behav Org 66:195-212

Rothaermel FT (2001) Complementary assets, strategic alliances, and the incumbent's advantage: an empirical study of industry and firm effects in the biopharmaceutical industry. Res Policy 30:1235-1251 
Rothaermel FT (2001) Incumbent's advantage through exploiting complementary assets via interfirm cooperation. Strateg Manag J 22:687-699

Rothaermel FT, Deeds DL (2004) Exploration and exploitation alliances in biotechnology: a system of new product development. Strateg Manag J 25:201-221

Sorenson O, Stuart TE (2001) Syndication networks and the spatial distribution of venture capital investments. Am J Sociol 106:1546-1588

Spence M (1973) Job Market Signaling. Q J Econ 87:355-374

Tykvová T, Schertler A (2014) Does syndication with local venture capitalists moderate the effects of geographical and institutional distance? J Int Manag 20:406-420

Uzzi B (1996) The sources and consequences of embeddedness for the economic performance of organizations: the network effect, American Sociological Review, 674-698

Villalonga B, McGahan AM (2005) The choice among acquisitions, alliances, and divestitures. Strateg Manag J 26:1183-1208

Walker G, Kogut B, Shan W (1997) Social capital, structural holes and the formation of an industry network. Org Sci 8:109-125

Yang H, Lin Z, Peng MW (2011) Behind acquisitions of alliance partners: exploratory learning and network embeddedness. Acad Manag J 54:1069-1080

Yang H, Zheng Y, Zhao X (2014) Exploration or exploitation? Small firms' alliance strategies with large firms. Strateg Manag J 35:146-157

Zaheer A, Bell GG (2005) Benefiting from network position: firm capabilities, structural holes, and performance. Strateg Manag J 26:809-825

Zaheer A, Hernandez E, Banerjee S (2010) Prior alliances with targets and acquisition performance in knowledge-intensive industries. Org Sci 21:1072-1091

Zollo M, Reuer JJ (2010) Experience spillovers across corporate development activities. Org Sci 21:1195-1212 